\title{
Physiology of citrus fruiting
}

\author{
Domingo J. Iglesias, Manuel Cercós, José M. Colmenero-Flores, Miguel A. Naranjo, Gabino \\ Ríos, Esther Carrera, Omar Ruiz-Rivero, Ignacio Lliso, Raphael Morillon ${ }^{1}$, Francisco R. Tadeo \\ and Manuel Talon*
}

Centro de Genómica, Instituto Valenciano de Investigaciones Agrarias, Apdo. Oficial, 46113 Moncada, Valencia, Spain. ${ }^{1}$ Centre de Coopération Internationale en Recherche Agronomique pour le Dévelopement (CIRAD), San Giuliano (Corse),F-20230,France.*Corresponding author: mtalon@ivia.es

Received: 31 October 2007; Accepted: 02 November 2007

Citrus is the main fruit tree crop in the world and therefore has a tremendous economical, social and cultural impact in our society. In recent years, our knowledge on plant reproductive biology has increased considerably mostly because of the work developed in model plants. However, the information generated in these species cannot always be applied to citrus, predominantly because citrus is a perennial tree crop that exhibits a very peculiar and unusual reproductive biology. Regulation of fruit growth and development in citrus is an intricate phenomenon depending upon many internal and external factors that may operate both sequentially and simultaneously. The elements and mechanisms whereby endogenous and environmental stimuli affect fruit growth are being interpreted and this knowledge may help to provide tools that allow optimizing production and fruit with enhanced nutritional value, the ultimate goal of the Citrus Industry. This article will review the progress that has taken place in the physiology of citrus fruiting during recent years and present the current status of major research topics in this area.

Key words: abiotic stresses, abscission, color break, flowering, fruit set, ripening

Fisiologia da frutificação em citrus. Citrus é a principal fruteira no mundo, tendo, portanto, profundos impactos econômicos, sociais e culturais em nossa sociedade. Nos últimos anos, o conhecimento sobre a biologia reprodutiva de plantas tem aumentado consideravelmente, principalmente em função de trabalhos desenvolvidos com plantas-modelo. Todavia, a informação produzida nessas espécies nem sempre pode ser aplicada a citrus, fundamentalmente porque citrus é uma cultura arbórea perene com uma biologia reprodutiva muito peculiar e incomum. A regulação do crescimento e desenvolvimento do fruto em citrus é um fenômeno complexo e dependente de muitos fatores externos e internos que podem operar tanto seqüencialmente como simultaneamente. Os elementos e mecanismos pelos quais estímulos ambientes e endógenos afetam o crescimento do fruto vêm sendo interpretados, e esse conhecimento pode auxiliar a prover ferramentas que permitiriam otimizar a produção per se, além da obtenção de frutos com maior valor nutricional, o objetivo precípuo da Industria de Citrus. Neste artigo, revisam-se os avanços que vêm ocorrendo na fisiologia da frutificação de citrus durante os últimos anos; apresenta-se, também, o status atual de pesquisas mais relevantes nessa área. Palavras-chave: estresses abióticos, floração, maturação, vingamento de frutos

\section{INTRODUCTION}

Fruit have been a matter of extensive research in recent years because of their importance to agriculture and the human diet. However, research on fleshy fruit has focused primarily on climacteric fruits such as tomato while other fruit models are not so well known. In this revision, we will review our understanding of citrus fruit development and will present it as a plausible model for tree and woody perennials. We will focus on the physiology of citrus fruiting, an area that complements the information presented in two upcoming reviews dealing with the generation of genomic tools and resources (Talon and Gmitter, 2008) and the progress in molecular biology and genetics of development (Tadeo et 
al., 2008) in the genus Citrus. The focus chosen for this review is on major physiological factors regulating fruit growth including flowering, hormones, carbohydrates and abiotic constrains. Also revised are major biochemical aspects of the ripening processes that may be important for fruit quality. A central part of the review concentrates on the hormonal and metabolic control of fruit set and development and documents progress in the understanding of abscission processes.

Economical and social relevance: Citrus is the most economically important fruit crop in the world, is grown in developed and developing countries and certainly constitutes one of the main sources of vitamin C. There is also an increasing demand of "high quality fresh citrus" driven by World Health Organization recommendations. Citrus contain the largest number of carotenoids found in any fruit and an extensive array of secondary compounds with pivotal nutritional properties such as vitamin E, provitamin A, flavonoids, limonoids, polysaccharides, lignin, fiber, phenolic compounds, essential oils etc. These substances greatly contribute to the supply of anticancer agents and other nutraceutical compounds with anti-oxidant, inflammatory, cholesterol and allergic activities, all of them essential to prevent cardiovascular and degenerative diseases, thrombosis, cancer, atherosclerosis and obesity. In spite of these beneficial traits there is still a major need to improve fruit quality to meet current consumer's demands.

Reproductive biology: From a scientific standpoint, citrus has proved to be valuable material for studying many biological questions because citrus combine an unusual mixture of reproductive characteristics including, for example, non-climacteric development. In contrast to climacteric fruits (reviewed in Giovannoni, 2004), the mechanism of ripening in non-climacteric fruits is basically unknown. Citrus also exhibit a long juvenility phase and nearly all important citrus species including sweet oranges, mandarins, lemons and grapefruits show some degree of apomixis. Furthermore, many of them are parthenocarpic, sterile or self-incompatible and/or develop defective pollen (Baldwin, 1993; Davies and Albrigo, 1994). In seeded citrus cultivars, fruit development is linked to the presence of seeds and, therefore, it depends upon pollination and fertilization.
Self-pollination usually takes place in the unopened or opening flower, often allowing pollination before anthesis. Cross-pollination occurs between plants of different genetic background by insect transport of pollen. However, many current citrus cultivars are mostly seedless varieties showing high parthenocarpy, in many instances due to gametic sterility. Generative sterility can be relative or absolute. Relative gametic sterility may be due to self-incompatibility as in Clementine and to crossincompatibility. On the other hand, absolute gametic sterility is associated with pollen and/or embryo-sac sterility. Some cultivars such as Washington Navel oranges and Satsuma mandarins have both, although even in these two varieties a few embryo sacs may often reach maturation.

Citrus fruits are also classified as hesperidiums, berries of very special organization characterized by a juicy pulp made of vesicles within segments. Thus, the combination of these characteristics suggests that the study of citrus fruit growth may reveal original regulation mechanisms based on specific molecular differences and/ or even novel genes (Forment et al., 2005; Cercós et al., 2006; Terol et al., 2007).

Citrus fruits are particularly convenient models to study regulation, for example, of secondary metabolism or sugar and citric acid build-ups and although many efforts have been certainly dedicated to comprehensive physiological and biochemical descriptive studies (see Baldwin, 1993) there is still an enormous unexplored potential in the study of the regulation of the metabolites associated with citrus fruit growth.

\section{CITRUS FRUIT SET AND GROWTH}

Fruit growth and abscission: In general, fruit formation in citrus pursues a genetic developmental program expressed over a relatively long period. In most species under subtropical conditions flowering takes place in spring and the subsequent formation of fruit extends until mid-winter. However, full ripening in early varieties may be reached as soon as September while in late species it can be prolonged until the onset of next summer. Growth and development of citrus fruit follows a typical sigmoid growth curve, divided into three clear-cut stages (Bain, 1958). The initial phase, or phase I, is an 
approximately two-month interval of cell division and slow growth including the period between anthesis and June drop. Thereafter, in the rapid growth period (phase II) fruit experiences a huge increase in size by cell enlargement and water accumulation during four to six months. Therefore, developing fruitlets are utilization sinks during the cell division period and act rather as storage sinks during phase II (Mehouachi et al., 1995). Finally, in phase III or ripening period growth is mostly arrested and fruits undergo a non-climacteric process.

Citrus bloom profusely and therefore also show high abscission of buds, flowers, fruitlets and fruits. It is interesting to note that although abscission of reproductive organs is overall continuous during phase I, two waves of elevated abscission take place at the onset of phase I and during the transition to phase II. Thus, bud, flower and ovary abscission occurs mostly at the beginning of the cell division phase, whereas fall of fruitlets and developing fruits is higher during the June drop. Generally, a small percentage of fruits overcome the June drop and in general less than $1 \%$ reaches ripening. The period in which fruit is liable to fall is referred to as fruit set and in this episode that can be extended along the whole phase I, several endogenous and exogenous factors configure the decision of either setting or aborting growth. The end of the period of fruit set usually coincides with the metabolic transition from cell division to cell enlargement. During phase II and phase III fruit abscission is considerably reduced although in some species and under adverse environmental conditions ripe fruits may show pre-harvest fall. Furthermore, in many varieties overripe fruit is quite insensitive to abscission. In citrus trees, flower and ovary abscission generally occurs through abscission zone A (AZ A, between the twig and the peduncle) that becomes progressively inoperative during phase I while abscission in zone C (AZ $\mathrm{C}$, in the calyx between the ovary wall and the nectary) is activated during June drop and at ripening.

Regulation of fruit set and growth: In seeded citrus, activation of the genetic programs regulating early growth and set depends mostly upon external stimuli of environmental nature, such as pollination, and hence of bloom quality. Aside from flowering intensity and the type of inflorescence, other major regulating factors can also be visualized since in seedless cultivars the initiation of these programs appears to be linked to the development. Although this proposal implies different kinds of control, many of them are probably operating through the synthesis and action of the same hormonal messengers. After activation, fruit growth is apparently supported by the availability of nutrients mostly mineral elements, carbohydrates and water. However, carbohydrate supply for the flower or fruit load is often insufficient and also favorable environmental conditions may eventually become adverse. Under these circumstances, new hormonal signals are generated to trigger temporal protection mechanisms, for example, stomata closure and growth arrest or even more drastic responses such as organ abscission. Therefore, the control of fruit growth and abscission in citrus is a complex phenomenon under at least three levels of regulation: genetic, metabolic and environmental. The distinct levels of regulation may act sequentially, simultaneously or can be superimposed on each other, although all three appear to operate partially through hormonal signals. Below, main physiological factors affecting fruit set and development are revised.

Citrus flowering: Citrus species show a relatively long juvenility period (two to five years) before the trees reach the mature stage to produce flowers. The inflorescence developed in citrus may be either leafless or leafy and these may carry a single flower or several of them (Goldschmidt and Huberman, 1974). The ratio of each kind of inflorescence in the tree varies with flowering intensity and cultivar. For example, high flowering intensities are generally related to high rates of leafless floral sprouts although some cultivars, such as Satsuma (C. unshiu Marc.) that tends to produce only vegetative shoots and single flower inflorescences, may show some particularities.

Citrus species usually produce a large number of flowers over the year. The floral load depends on the cultivar, tree age and environmental conditions (Monselise, 1986). It has been reported, for example, that sweet oranges (C. sinensis) may develop 250,000 flowers per tree in a bloom season although only a small amount of these flowers (usually less than $1 \%$ ) becomes mature fruit (Erickson and Brannaman, 1960; Goldschmidt and Monselise, 1977). Thus, flowering represents a great input for citrus trees and to some extent even a waste of 
resources. For some authors, however, this reproductive pattern may be linked to a survival strategy (Bustan and Goldschmidt, 1998).

Flowering induction: In subtropical regions, citrus major bloom occurs during the spring flush along with the vegetative sprouting. Under these environmental conditions, flowering takes place after a period of bud quiescence and the exposure to the low temperatures and short days of winter (Figure 1). Generally, summer and fall flushes are less intense and produce almost exclusively vegetative shoots. The importance of temperature as a major factor of flower induction is well established and has been recognized for a long time (Moss, 1969; Altman and Goren, 1974; Guardiola et al., 1982; Valiente and Albrigo, 2004; Nebauer et al., 2006). Several authors have proposed that low temperatures may have a dual effect releasing bud dormancy and inducing flowering (Southwick and Davenport, 1986; García-Luis et al., 1989, 1992; Tisserat et al., 1990). Moreover, temperatures under $20^{\circ} \mathrm{C}$ have been demonstrated to contribute to flower bud induction in a time dependent manner (Moss, 1969; Southwik and Davenport, 1986; García-Luis et al., 1992).

In tropical climates, however, bud sprouting and flowering come about without interruption throughout the year although the main bloom still occurs during the spring (Monselise, 1985; Spiegel-Roy and Goldschmidt, 1996). In contrast to the sub-tropical stimuli, in tropical conditions citrus apparently flower in response to drought periods. In addition to low temperature, water deficit has also been recognized for a long time as another strong inductor of flowering in citrus (Cassin et al., 1969). Moreover, water deficit has been proved to increase the ratio of floral shoots and the total number of flowers (Southwick and Davenport, 1986).

It should be noted that several citrus species and varieties also show a wide range of behaviors regarding both flowering time and response to the inductive conditions. For example, lemon trees tend to show sparse flowering over the year even in subtropical conditions (Nir et al., 1972) and also exhibit higher floral responses to waters stress than to cold inductive temperatures (Chaikiatiyyos et al., 1994). This effect has been commercially used to induce off-season flowering (Davies and Albrigo, 1994).

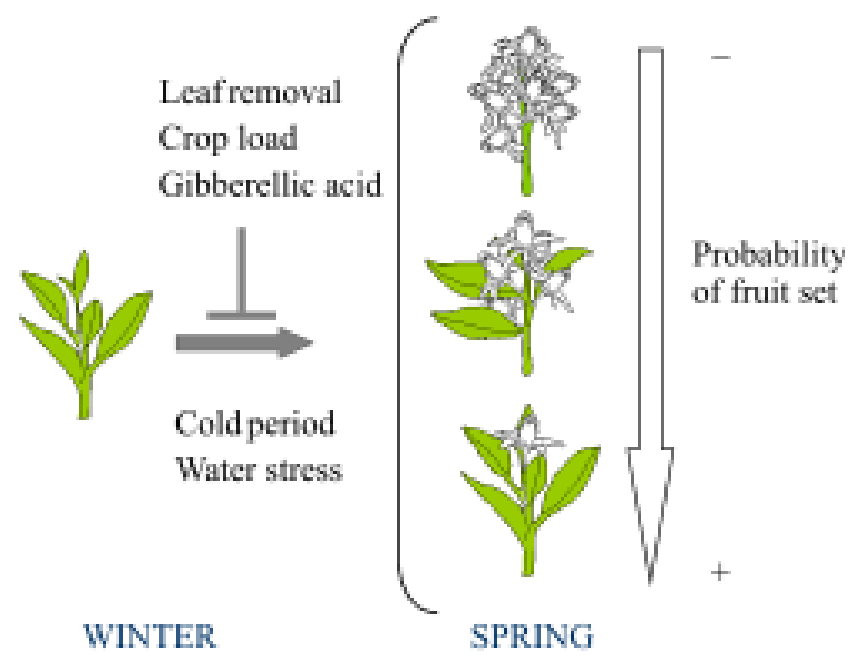

Figure 1. Regulation of citrus flowering. In subtropical regions, citrus bloom generally occurs during the spring flush along with vegetative sprouting. In these areas, flowering takes place after a period of bud quiescence and the exposure to the low temperatures and short days of winter. In tropical regions and in areas with drought seasons citrus also flower in response to re-hydration after a period of water deficit. Huge fruit load, leaf removal and exogenous gibberellic acid reduce flowering, normally decreasing the rate of leafless shoots. The probability of fruit set, represented as a downward arrow, is inversely related to the number of flowers within the shoot.

There are many instances suggesting that the flowering response to inductive conditions is also influenced by endogenous factors. For example, citrus buds on previous summer shoots and buds at apical positions produce more flowers than older or lateral buds (Valiente and Albrigo, 2004). It is also well known that the fruit load has a strong negative effect on spring sprouting of both vegetative and generative buds and therefore constitutes a major inhibitor of flowering. Conversely, the absence of fruit or a scarce fruiting induces huge flowering intensities in the next season. Thus, crop load is likely the main cause of the "alternate bearing" behavior of many citrus species and varieties including many seeded mandarins that alternate reduced flowering and fruiting ("off year") with increased flower induction and fruit production ("on year"). From an agronomical point of view, undesirable flowering behaviors such as alternate bearing may be partially alleviated by different treatments inhibiting or promoting flower production. The flowering response to fruit load has been attributed to carbon 
shortage that provokes the presence of fruit and/or to the release of signaling compounds, mainly gibberellins from the ripe fruits (Monselise, 1985; Garcia-Luis et al., 1986; Erner, 1988; Koshita et al., 1999).

The role of sugars on flowering induction is mostly supported by circumstantial evidence. For example, it is known that "girdling", the removal of a bark ring, increases flower induction and it has been suggested that this stimulating effect is due to the transitory block of phloem flux that apparently increases sugar availability in the aerial parts of the tree (Wallerstein et al., 1978; Yamanishi, 1995).

Gibberellin treatment is a common agricultural practice that is currently used to inhibit flowering in citrus trees. Applications of gibberellic acid during citrus bud development have been widely shown to inhibit flower production (Guardiola et al., 1982), leading to a greater ratio of terminal flowers in leafy shoots and consequently a higher fruit development. This observation is in contrast to the reported flowering promoting effect of gibberellin on annual plants such as Arabidopsis thaliana. Despite the absence of a mechanism to cope with this observation, the flower repressing effect of gibberellins is corroborated by treatments with the inhibitor of GA biosynthesis paclobutrazol, which consistently induces flowering when applied to the field. Furthermore, the treatments with GA synthesis antagonists are not effective when GA is already present at high levels. Bud treatments with gibberellins also reduce summer bud sprouting (Lliso et al., 2004). Other growth regulators and phytohormones have also been assayed with variable results. Benzyladenine, for instance, has been suggested to have a specific effect on flower differentiation (Iwahori et al., 1990) and to promote general bud sprouting in vitro (Altman and Goren, 1978) and in whole trees (Nauer and Boswell, 1981; Lliso et al., 2004).

Plant nutrition status has also been associated with citrus flowering. Higher contents of $\mathrm{N}$ (ammonia), in particular, in the buds and leaves altered by winter application of urea increased the number of flowers per tree (Lovatt et al., 1988; Albrigo, 1999). Similarly, N fertilization over three years has been shown to improve canopy width and flower yield (Menino et al., 2003).
Recently, molecular mechanisms regulating flowering in citrus were investigated in relation to DNA methylation in buds but no clear, conclusive results were reported (Neubauer et al., 2006).

Leafy versus leafless inflorescences: Although citrus species may show some differences in the initiation of flower formation (Abbot, 1935), floral differentiation has been reported to occur close to the end of the cold season, just at bud sprouting (Guardiola et al., 1982; Lord and Eckard, 1985). Actually, the first morphological differences between reproductive or vegetative buds are only observable at this moment (Davenport, 1990). Citrus fruit set is highly dependent upon the type of inflorescence. In general, leafless inflorescences emerge first and contain a bouquet of flowers with low probability to set fruit. On the other hand, flowers in leafy inflorescences that can be terminal or distributed among leaves along the shoot are commonly associated with higher fruit set (Jahn, 1973). Usually, late-opening flowers remain attached to the tree longer than early-opening flowers and flowering shoots with a high leaf-to-flower ratio have the highest fruit set (Lovatt et al., 1984). The positive influence of leaves on fruit set appears to be associated with increased net $\mathrm{CO}_{2}$ assimilation and supply of photoassimilates from developing leaves (Syvertsen and Lloyd, 1994). These might also influence ovary growth and fruit set through the provision of gibberellins since leafy inflorescences contain higher hormonal levels than leafless ones (Ben-Cheikh and Talon, unpublished results).

Pollination and parthenocarpy: In general, fruit set also depends on successful pollination and fertilization since the presence of fertilized ovules normally triggers fruit development. In seeded citrus, the decision to initiate fruit development certainly requires pollination and fertilization. If the flower is not pollinated, the development of the gynoecium arrests, the whole flower senesces and eventually abscises. In the seeded sweet orange cultivars of 'Pineapple' for example, lack of fertilization will inevitably lead to abscission of the ovary since all emasculated and non-pollinated flowers arrested growth and fell shortly after anthesis (Ben-Cheikh et al., 1997). Growth arrest of unpollinated ovaries is mostly due to a failure in the re-activation of cell division as is seen in 
the pollinated fruitlet (Ben-Cheikh et al., 1997). Thus, fruit set in this cultivar is strictly dependent on pollination and fertilization. The duration of the bloom period is linked to temperature regimen (Spiegel-Roy and Goldchmidt, 1996). High temperatures accelerate anthesis and shorten the bloom period while low temperatures lead to an extended flowering period (Lovatt et al., 1984; Bellows and Lovatt, 1989; Davenport, 1990). Thus, temperature conditions may have important consequences for the chances of pollination and fruit set. Temperature also affects the activity of bees, the main citrus pollinators, and the growth rate of pollen tubes. Under standard temperature conditions, the effective pollination period varies in citrus cultivars between $8-9 \mathrm{~d}$ for sweet oranges and Clementine mandarins to 2-3 d for Satsuma mandarins (Mesejo et al., 2007). In addition to temperature, several other factors such as flower number (Moss, 1973; Valiente and Albrigo, 2004), inflorescence type, floral position (Lovatt et al., 1984) and nutritional status may also affect flower formation and development and therefore fruit set.

However, many current commercial citrus cultivars are seedless varieties since their fruit are often well appreciated for their ease of consumption. There are also several classes of seedlessness in commercially available citrus fruit ranging from self-incompatible cultivars such as Clementine mandarin that show a lower ability to set fruit in the absence of cross-pollination to the truly seedless Satsuma mandarins and Navel sweet oranges, that generally set a normal crop of parthenocarpic fruit, due to high masculine and feminine gametic sterility (Frost and Soost, 1968). In these varieties, parthenocarpic fruit develop without formation of seeds and therefore all pollination, fertilization or seed requirements for fruit growth activation have clearly been substituted by endogenous signals. Self-incompatible cultivars show a low degree of parthenocarpy and therefore can be considered to possess "facultative parthenocarpy" meaning that seedless fruit form only when fertilization does not occur.

Hormonal regulators of fruit growth and abscission: Early reproductive processes in citrus are strongly affected by plant growth regulators indicating that the regulatory mechanism controlling set and abscission of ovaries and fruitlets possesses a pivotal hormonal component (Talon et al., 1990b). Overall, these studies suggest that a complex set of hormonal interactions occur during fruit development. Thus, gibberellins (GAs) and cytokinins are generally considered to be positive regulators of fruit growth while auxins have been reported to act as stimulators of growth and also as abscission agents. Abscisic acid (ABA) and ethylene have been implicated in several ways in abscission.

Gibberellins: Gibberellins are thought to be pivotal effectors responsible for the ovary-fruit transition (Talon et al., 1992; Ben-Cheikh et al., 1997). Gibberellins activate cell division and cell enlargement processes in vegetative organs (Talon et al., 1991) and therefore are generally associated with the initiation of growth (Talon and Zeevaart, 1992). The endogenous GAs found in citrus fruits are mainly members of the 13-hydroxylation pathway $\left[\mathrm{GA}_{53}, \mathrm{GA}_{97}, \mathrm{GA}_{44}, \mathrm{GA}_{17}, \mathrm{GA}_{19}, \mathrm{GA}_{20}, \mathrm{GA}_{29}, \mathrm{GA}_{1}\right.$,

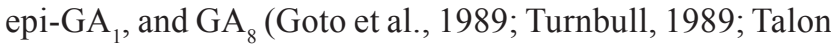
et al., 1990a, 1992)] leading to $\mathrm{GA}_{1}$, the bioactive GA (Zeevaart et al., 1993). This pathway also operates in vegetative tissues of citrus (Vidal et al., 2001, 2003) where is thought to control shoot growth and elongation (Fagoaga et al., 2007). Developing fruits also contain at lower levels $3 ß$ - and non-hydroxylated GAs, such as $\mathrm{GA}_{4}$, $\mathrm{GA}_{24}, \mathrm{GA}_{25}$, and $\mathrm{GA}_{9}$. It is generally accepted that GAs are involved in set and development of citrus fruits. The support for this proposal comes from several studies reporting that exogenous $\mathrm{GA}_{3}$ considerably improves parthenocarpic fruit set and growth of self-incompatible genotypes such as Clementine that in the absence of cross-pollination show negligible parthenocarpic fruit set (Soost and Burnett, 1961). Later, it was found that these genotypes also contain lower $\mathrm{GA}_{1}$ levels than the seedless varieties that show natural parthenocarpy (Talon et al., 1992). In developing fruits, the $\mathrm{GA}_{1}$ levels are low just before and after anthesis and approximately double at anthesis. This transitory rise in $\mathrm{GA}_{1}$ levels can be detected in seeded genotypes as well as in seedless cultivars possessing high or normal ability for setting (Talon et al., 1990a). In seeded cultivars, GA increases at anthesis are therefore induced by pollination whereas in parthenocarpic species the rise is developmentally regulated. The intensity of abscission during the initial phases of growth is also related to the phenology of flowering. Interestingly, the presence of leaves increases 
$\mathrm{GA}_{1}$ levels (Ben-Cheihk and Talon, unpublished results) and the chances of setting (Lovatt et al., 1984). In seeded cultivars, pollination stimulates hormonal synthesis and, therefore, increases $\mathrm{GA}_{1}$ levels in developing ovaries (Ben-Cheikh et al., 1997). It has also been shown that in seeded varieties exogenous GA arrested fruit drop of non-pollinated ovaries. Collectively, these observations indicate that the increase in $\mathrm{GA}_{1}$ detected in mature ovaries shortly after pollination is a signaling stimulus of the regulatory mechanism that reactivates fruit development after anthesis.

Cytokinins: Cytokinins are also factors stimulating cell division. Increases in their levels have also been found in developing ovaries at anthesis (Hernández and PrimoMillo, 1990), as reported for GAs. In addition, exogenous cytokinins have been reported to enhance parthenocarpic fruit development and stimulate sink strength in developing fruits of certain cultivars, although these regulators are not commercially used to improve fruit set in citrus.

Auxins: These regulators have often been reported either to delay or to induce fruit abscission, and hence may operate as growth hormones or as abscising agents. On one hand, auxins promote cell enlargement rather than cell division. Although endogenous auxins also increase in developing ovaries, it is well established that exogenous treatments do not improve fruit set. Auxins are also high during the beginning of phase II, the period of cell elongation, and it is at this moment when exogenous auxins are effective increasing fruit size (Coggins and Hield, 1968). These observations may suggest that auxins are related to cell enlargement, the essential factor controlling fruit size during the phase of rapid growth. The enlargement of the auxin-treated fruits is apparently due to cell expansion rather than to cell division. In tomato, for example, it has been postulated that auxins are part of the hormonal signaling transduction network controlling cell expansion (Catala et al., 2000). On the other hand, auxins may act either as delaying or accelerating agents of abscission. During the initial phases of abscission auxins operate as inhibitors, but once the process has been initiated auxins appear to stimulate abscission. Here, auxins could operate through the promotion of ethylene synthesis. It has also been suggested that the causal reason of the dual effect of auxins on leaf abscission may conveniently be explained by the auxin-gradient concept: auxin coming from the leaf would tend to delay abscission, whereas auxin moving down the stem might promote abscission. In citrus, synthetic auxins increase abscission of developing fruitlets during the cell division period. Auxin applications at the beginning of the cell enlargement period may have minor effects preventing on fruit abscission and result in fruit size increase. The prevention or retardation effects of auxins on abscission can be perceived, however, at later stages. At the end of phase II or at the onset of phase III, synthetic auxins are commercially used to prevent or delay eventual preharvest fruit drop (e.g. Agustí et al., 2002).

Abscisic acid: Although many field experiments have demonstrated that ABA does not cause abscission when applied to the aerial part of the plant, many observations suggest that ABA, in addition to ethylene, is implicated in the process of abscission (Goren, 1993). Abscisic acid is high in developing ovaries at petal fall and during the June drop, at the transition from cell division to cell enlargement. Interestingly, these two ABA increases coincide with the abscission waves occurring at the onset of phases I and II. This hormone is also high over periods of lower humidity, dehydration and salt or drought conditions (Gomez-Cadenas et al., 2003a; Mehouachi et al., 2005; Agustí et al., 2007).

Ethylene: At the beginning of the past century, ethylene was identified as the component responsible for several adverse effects on plant growth including the induction of abscission. In the 1960's it was generally accepted that plants could produce significant amounts of ethylene (Brown, 1997). In citrus, the involvement of ethylene in abscission has also been recognized for a long time (Goren, 1993). It has also been shown that ethylene is the pivotal hormonal factor promoting the processes of leaf abscission (Tudela and Primo-Millo, 1992).

Hormonal balances: One of the current hypotheses on the hormonal regulation of abscission suggests that the balance between specific plant growth regulators at the abscission zone controls cell separation processes and eventually fruit drop (Addicott, 1982; Goren, 1993; Brown, 1997). In citrus organs, the effect of the auxin/ ethylene balance, for example, has been largely 
associated with the abscission of fruit, leaves and flowers. Thus, it has been suggested that auxin levels must fall below a certain threshold in the citrus abscission zone before ethylene can stimulate abscission (Goren, 1993). In another example, the crucial factor controlling abscission appears to be the balance between indole-acetic (IAA) acid and ABA in the fruit abscission zone (Cooper and Henry, 1972). Thus, during the fruitharvesting season of sweet oranges, the abscission response of fruits to several abscission chemicals varied considerably and the periods of low effectiveness coincided with higher and lower indole-acetic acid and ABA levels, respectively, in the calyx abscission zone (Yuan et al., 2001). These observations exemplify the role of endogenous auxins antagonizing or delaying citrus fruit abscission, but as suggested above there are other instances showing inductive effects of auxins on abscission. Thus, the postbloom fruit drop disease provoked by fungus infection and characterized by premature fruit abscission has been associated with increases of ethylene production and IAA and jasmonic acid (JA) amounts in the infected petals (Lahey et al., 2004). Consistently, the application of both auxin transport and action inhibitors and JA biosynthesis inhibitors after infection improved fruit retention suggesting an inductive role of IAA and JA on young fruit abscission (Chen et al., 2006). These observations, apparently, illustrate the dissimilar effects of auxins preventing and inducing abscission. It has also been reported that treatments with methyl-jasmonate to mature citrus fruit are also able to induce abscission (Hartmond et al., 2000).

Regulation of fruit set: The above evidence suggests that hormonal deficiencies, mostly reductions of GA levels over the anthesis period, result in subsequent ovary and fruitlet drop. These effects are apparent in both self-incompatible varieties such as Clementine and in non-pollinated ovaries of seeded cultivars. Consistently, GAs increase at anthesis while ABA is low shortly thereafter in cultivars having low abscission rates (García-Papí and García-Martínez, 1984; Talon et al., 1992). Again, the opposite can be found in selfincompatible species. Furthermore, exogenous ABA increases ACC synthesis, ethylene production and abscission in citrus fruit explants (Goren, 1993), whereas exogenous GAs suppress completely both post-anthesis ABA increases and fruit abscission (Zacarias et al., 1995). Likewise, pollination increases GA levels and reduces fruit abscission in seeded varieties, whereas emasculation reduces the GA content and increases abscission. Once more, exogenous GAs suppress fruit abscission of emasculated ovaries (Ben-Cheikh et al., 1997).

Taken together, it is concluded that GA deficiency is associated with $\mathrm{ABA}$ rise, ethylene release and eventually ovary abscission (Figure 2). Interestingly, this hormonal sequence is induced by other unfavorable conditions such as carbon shortage or water deficit also provoking growth arrest and fruit abscission, as we will see below. Thus, a single hormonal pathway triggering abscission appears to be induced through a variety of developmental and environmental stimuli.

The observation that GAs are able to induce parthenocarpic fruit development in seeded citrus is crucial to understand the GA role in fruit set. Thus, in seeded sweet orange, parthenocarpic fruit development can be triggered by exogenous applications of gibberellins to emasculated and unfertilized gynoecia. This exogenous supply is thought to substitute the endogenous hormones normally provided by the seeds. Fruit treated with GA set and elongated as much as pollinated fruit during the first phase of growth just until June drop. However, none of these GA treated parthenocarpic fruit overcame June drop and came close to reach maturation and ripening (Ben-Cheikh et al., 1997) suggesting that although GA may counteract the failure in the hormonal signaling during the first phase of growth, other pivotal factors in seeded varieties are required during June drop and thereafter. Hence, exogenous GAs set fruit and trigger initial seedless fruit development in both "facultative" and "truly" parthenocarpic varieties although only in facultative cultivars is fruit growth fully completed until ripening. These observations indicate both that GAs are pivotal factors controlling initial fruit set and that other components are also essential during June drop.

The role of carbohydrates: After hormonal induction of fruit growth, nutrients may have regulatory functions on their own and/or through the maintenance of adequate hormonal levels (Gillaspy et al., 1993). The average 


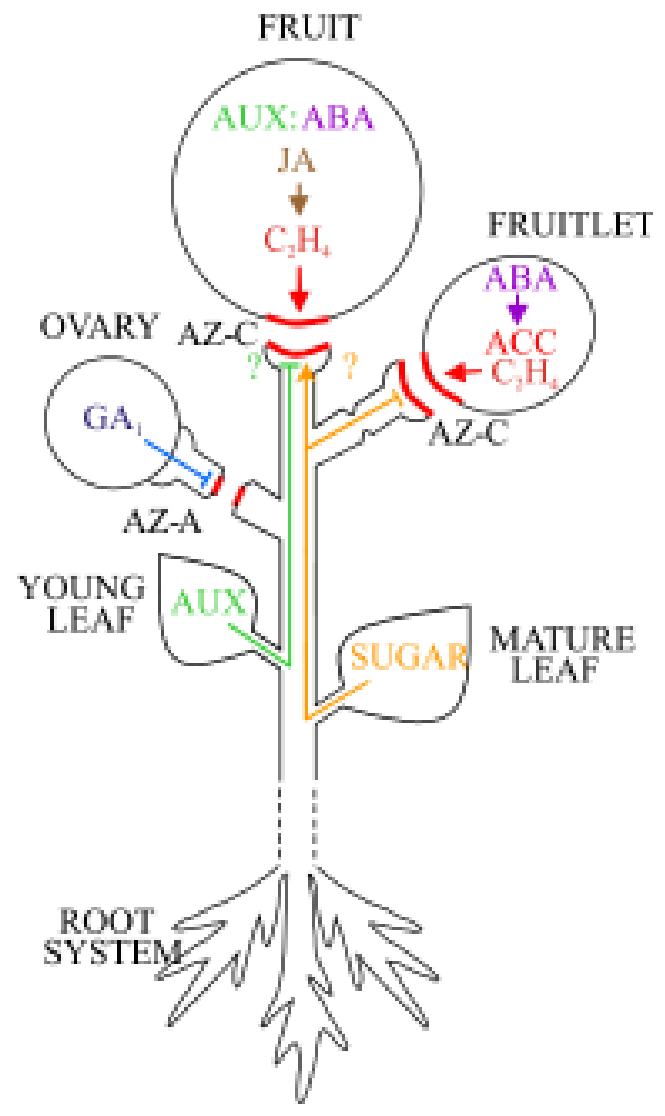

Figure 2. Regulation of citrus fruit abscission. Flower and ovary abscission through abscission zone (AZ) A (AZ-A) located between branch and the peduncle occurs at the branch and the peduncle (AZ-A) occurs at the beginning of the fruit-set period and is negatively regulated by the endogenous levels of $3 \beta$-hydroxylated gibberellins such as $\mathrm{GA}_{1}$ in ovaries. Fruitlet abscission during June drop occurs at the end of the fruit-set period through AZ-C located in the calyx, in the interface between the floral disc and the ovary wall, and is highly dependant on carbohydrate availability. Sugars in mature leaves are transported to growing fruitlets and presumably inactivate AZ-C. Carbon shortage in fruitlets induces sequential increases in abscisic acid (ABA) and 1-aminocy clopropane-1-carboxylic acid (ACC, the immediate precursor of ethylene). This precursor is further oxidized to ethylene $\left(\mathrm{C}_{2} \mathrm{H}_{4}\right)$ and the release of the gas activates fruitlet abscission. In contrast to developing fruitlets, in mature ripe fruits sugar accumulation might have an inductive role on the activation of pre-harvest abscission. It has also been suggested that the balance between $\mathrm{C}_{2} \mathrm{H}_{4}$, acting as an accelerator of the process, and auxin (AUX) acting as an inhibitor, is one of the key factors regulating abscission of ripe fruit. In this model, AUX synthesized in young leaves and transported to mature fruit operates as negative regulator of abscission protecting AZs from high
$\mathrm{C}_{2} \mathrm{H}_{4}$. The positive regulatory role of jasmonic acid (JA) on fruit abscission is thought to be mediated through $\mathrm{C}_{2} \mathrm{H}_{4}$ biosynthesis stimulation. The balance between AUX and ABA in mature fruits may also be important in determining AZ-C sensitivity to the abscission stimulus. Arrows and T-shaped lines indicate positive and negative regulation, respectively.

number of flowers produced in a normal citrus tree is by far extremely high in comparison with the number of fruits that the same tree can support until ripening. Hence, many fruits are abscised during growth apparently due to competition for nutrients especially photoassimilates. During the initial moments of phase I, citrus fruitlets function as carbohydrate utilization sinks but over the final stages of this period and during the transition from cell division to cell enlargement, developing fruits shift their metabolism and start to behave as storage sinks (Mehouachi et al., 1995). Interestingly, defoliation during phase I reduces carbohydrate amounts, arrests fruitlet growth and promotes massive abscission (Mehouachi et al., 1995, 2000) whereas defoliation after the June drop also arrests growth but does not induce abscission (Lenz, 1967).

The link between carbohydrates and fruit growth is currently supported by a wide body of evidence including several studies on source-sink imbalances, defoliation, girdling, shading, sucrose supplementation, defruiting and fruit thinning (Goldschmidt and Koch, 1996; Iglesias et al., 2003; Syvertsen et al., 2003). First, the enhancement of carbohydrate availability was associated with an improvement of fruit set and yield of citrus trees (Goldschmidt, 1999). Later, a strong relationship was demonstrated between carbohydrate levels available to fruitlets and the probability of abscission (GómezCadenas et al., 2000; Iglesias et al., 2003). This phenomenon that has also been described for other tree species is also supported by studies on translocation of ${ }^{14} \mathrm{C}$ metabolites and $\mathrm{CO}_{2}$-enrichment experiments (Moss et al., 1972; Downton et al., 1987). Hence, photosynthesis activity has been proved to be crucial since high carbohydrate requirements during fruit set increases photosynthetic rate (Iglesias et al., 2002). This suggestion also implies that a reduction in net $\mathrm{CO}_{2}$ assimilation results in lower sugar production and fruit set. Moreover, in this work it was proposed that sugar 
concentration in leaves might be the signal that regulates the feed-back mechanism stimulating photosynthesis in response to fruit sugar demand. Thus, once carbon demands are fulfilled, carbohydrate accumulation may elicit end-product feedback control of photosynthesis. For example, it is known that ringing that generally increases fruit set and carbon availability (Iglesias et al., 2006 b) probably because of the transitory block of phloem flux transport (Wallerstein et al., 1978; Yamanishi, 1995) also represses total photosynthetic activity (Iglesias et al., 2002). Indeed, girdling decreases photosynthesis in the bulk of developing vegetative shoots but stimulates it in leafy fruiting shoots (Rivas et al., 2007). An additional interesting observation relies on the fact that the positive effect of both pollination and exogenous GAs on fruit set and growth may also partially operate through the induction of a stronger mobilization of ${ }^{14} \mathrm{C}$ metabolites to ovaries (Powell and Krezdorn, 1977). Furthermore, exogenous GAs have also been shown to stimulate growth and increase carbon supply in vegetative tissues (Mehouachi et al., 1996). Collectively all this information indicates that sugars are deeply implicated in the regulation of fruitlet growth and that overall carbon deficiency induces fruit abscission.

Regulation of June drop: Although the specific mechanism involved in the response of fruit growth to carbohydrates has not been studied at the molecular level many observations suggest that sugars may act not only as essential nutrient factors but also as signals triggering specific hormonal responses (see for example Zhou et al., 1998; Roitsch, 1999). As above, the essential observation linking carbohydrate and abscission was the finding that carbon shortage during ovary and fruitlet drop increased ABA and ethylene and that both are involved in the induction of early abscission (Gómez-Cadenas et al., 2000). This information was provided by defoliation treatments that in citrus do not change the water status of the developing fruits but do alter considerably the nutrient supply (Mehouachi et al., 1995). The alterations in the nutrient balance that are accompanied with increased fruitlet abscission during the June drop provoke an unambiguous tendency to both increase nitrogen content and to reduce carbon shortage. Interestingly, abscission intensity correlated positively with carbohydrate shortage and later it was also demonstrated that the increases in the abscission rates induced by different defoliation treatments paralleled ABA and ACC levels detected in the abscinding fruitlets (Gómez-Cadenas et al., 2000). The simplest interpretation of these observations suggests that ABA acts as a sensor of the intensity of the nutrient shortage modulating the levels of ACC and ethylene, the final activator of abscission. Manipulative experiments of the amounts of endogenous hormones also led to the conclusion that, although the ABA rise precedes the ACC increase, both are certainly required for fruit abscission. Thus, two main conclusions can be extracted from these observations: first, that the fruit fall that takes place during June drop is very likely due to the carbohydrate insufficiency caused by an increased carbon demand of a huge population of expanding fruitlets; and second, carbon deficiency is again associated with ABA rise, ethylene release and massive fruitlet abscission (Figure 3 ), that is, with the hormonal sequence suggested to operate in developing reproductive structures during early ovary to fruitlet transition (see above) and also during water stress-induced abscission (see below). Interestingly, this hormonal abscission pathway appears to be induced through a variety of developmental and environmental stimuli.

This idea that citrus fruit abscission is connected to carbohydrate availability was initially anticipated by Goldschmidt and Monselise (1977) who suggested that citrus might possess an internal self-regulatory mechanism that adjusts fruit load to the ability of the tree to supply metabolites. The above findings identify leaf sugar content, ABA and ethylene as major components of the self-regulatory adjusting mechanism visualized by these authors. The proposed hormonal sequence also offers a plausible explanation for the naturally occurring abscission and physiological bases for the photoassimilate competition hypothesis.

Recently, it has also been proposed that in addition to June drop, earliest ovary and fruitlet falls that occur through abscission zone A, are also dependent upon nutritional factors such sugars (Iglesias et al., 2006b). However, the data presented suggested that in this process ethylene constitutes a necessary but insufficient component of the activation mechanism. 


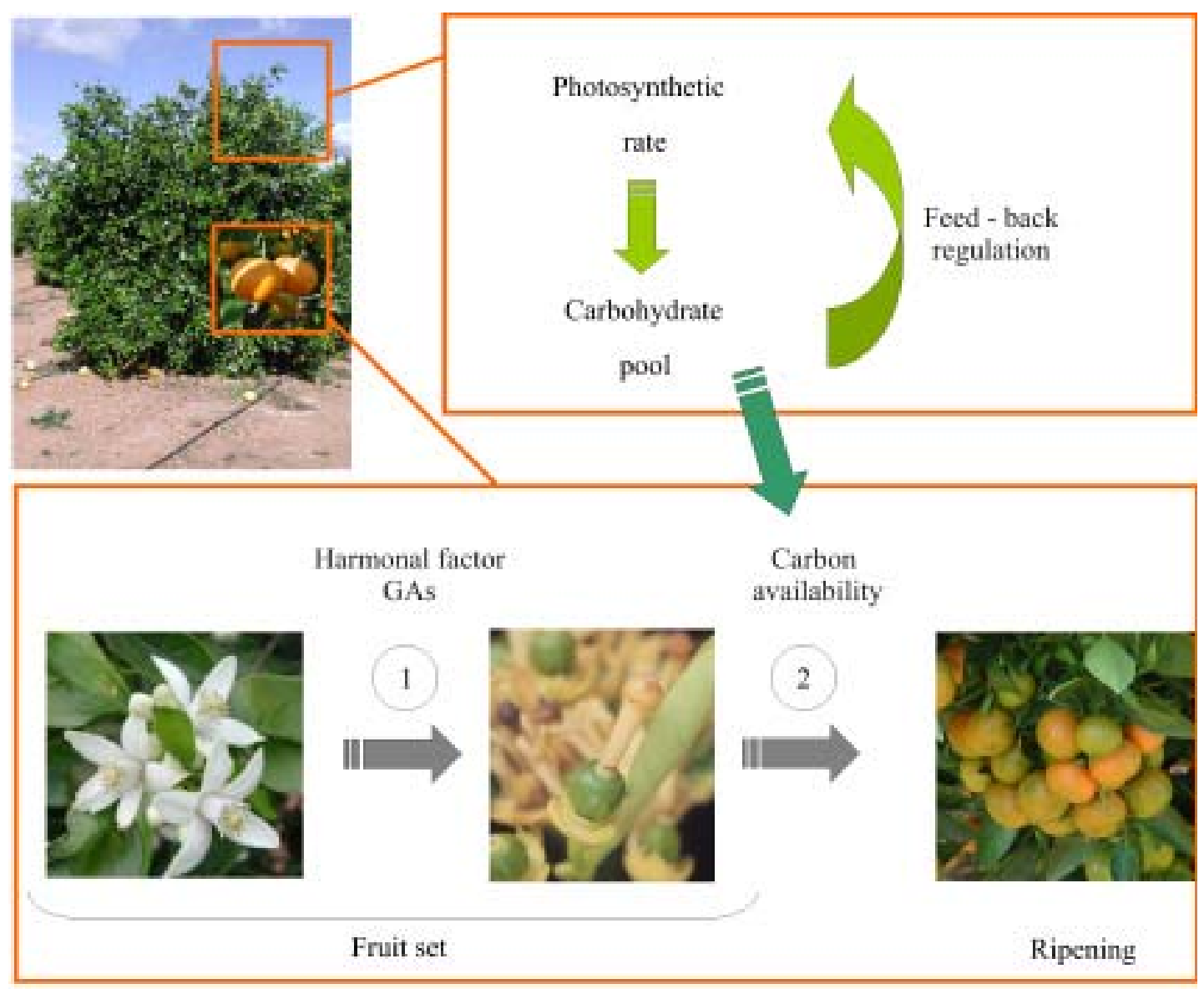

Figure 3. Regulation of citrus fruit set and growth. Aside from flowering, other major regulating factors of fruit set and growth are the gibberellin and carbohydrate supplies. Gibberellins are thought to be pivotal effectors responsible of the transition of ovary-fruit, the initial fruit set. After growth activation, fruit development is apparently supported by the availability of nutrients, mostly mineral elements, carbohydrates and water. There is considerable evidence that June drop is very likely due to the carbohydrate shortage caused by an increased carbon demand of a huge population of expanding fruitlets. Sugar concentration in leaves appears to be the signal that regulates the feed-back mechanism stimulating photosynthesis in response to sugar fruit demand.

\section{CITRUS FRUIT RIPENING}

Fruit ripening and quality: Citrus fruits belong to a special type of berry named hesperidium, composed of two major, morphologically distinct regions: the pericarp (peel or rind) and the endocarp (pulp), which is the edible portion of the fruit. The pericarp is further divided into two parts: the exocarp (flavedo), which is the external colored portion and the mesocarp (albedo), the white layer of the peel. The pulp consists of segments, the ovarian locules, enclosed in a locular membrane and filled with the juice vesicles that are the ultimate sink organ of the citrus tree. During non-climacteric ripening, active growth in citrus fruits slows down and metabolism shifts to integrate a number of biochemical and physiological changes that eventually render an edible organ. In ripe fruits, ethylene production and sensitivity is low, respiration is considerably attenuated and changes in texture and composition proceed gradually (Aharoni, 1968; Eaks, 1970; Goldschmidt et al., 1993). Furthermore, there is no evidence that any specific hormone controls the whole process of ripening.

Fruit quality traits are acquired along stages II and III during fruit development and maturation. In a broad sense, fruit quality in citrus is related to many physical properties including size, shape, color, texture, seed number, peelability etc. and to the chemical components of the fruit, among them sugars, acids, flavor compounds, 
volatiles and other nutraceutical substances such as vitamin $C$. These properties that ultimately are dependent on the regulation of the physiological and biochemical processes determining fruit growth have a strong economical relevance since they are related to consumer perception and eventually constrain the success of the Citrus industry.

Although external and internal ripening in general coincide, peel and pulp behave in many respects as separate organs and thus can be considered as different physiological processes. In this descriptive review, external and internal ripening processes will be discussed separately.

External ripening: The process of external citrus fruit ripening is mostly dependent upon the conversion of chloro- to chromoplasts and involves the progressive loss of chlorophylls and the gain of carotenoids, thus changing peel color from green to orange (Huff, 1983, 1984). The changes associated with external ripening are essentially comparable to the senescence of vegetative chlorophyllous tissues and in citrus fruits are influenced by environmental conditions, nutrient availability and hormones (Goldschmidt, 1988; Iglesias et al., 2001). Color break in subtropical areas generally takes place in midautumn when temperatures go down and day length diminishes (Figure 4). The decline in rind chlorophyll proceeds over several months and the onset of carotenoid accumulation almost coincides with the disappearance of chlorophyll. Just prior to carotenoid build-up there is a transition from carotenoids of the photosynthetic chloroplast to the intensely colored carotenoids of the chromoplast (Eilati et al., 1969; Gross, 1987). In citrus, chromoplast biogenesis is of particular interest and agronomical relevance, since unlike most ripening processes the chloro- to chromoplast conversion is reversible, even from fully differentiated chromoplasts (Goldschmidt, 1988).

It has been known for a long time that regulatory mechanisms involving phytohormone control are deeply involved in chloroplast transformation (Bruinsma et al., 1975; McGlasson et al., 1978; Goldschmidt, 1988; BenArie et al., 1995; Guis et al., 1997). Thus, ethylene is being used for the last half century to stimulate color change in citrus fruits during post-harvest storage. In spite of this well-known effect, as yet no clear role for endogenous ethylene in citrus ripening has been demonstrated. It has been suggested that ethylene is synthesized in citrus fruit through typical system I machinery although an additional system II-like process appears to operate in young fruitlets (Katz et al., 2004). Mature citrus fruits release very low amounts of ethylene although they respond to exogenous ethylene accelerating color break through both chlorophyll degradation and carotenoid deposition. Exogenous ethylene certainly accelerates chlorophyll disappearance and increases chlorophyllase activity (Trebitsh et al., 1993; Azuma et al., 1999; JacobWilk et al., 1999; Fujii et al., 2007). In contrast, GA 3 partly counteracts the ethylene-induced increase in chlorophyllase (Trebitsh et al., 1993) delaying degreening (Cooper and Henry, 1968). This observation is consistent with many field observations of de-greening delay or even fruit re-greening associated with the GA treatment (Porat et al., 2001). It has also been suggested that color break of citrus fruit is controlled by nutrients. Based on data collected from in vitro studies on citrus epicarp, Huff $(1983,1984)$ suggested that citrus fruit might partially de-green in response to the accumulation of sugars. It has specifically been shown that the chloroto chromoplast conversion in citrus fruit epicarps is stimulated by sucrose accumulation after an initial decrease in peel nitrogen content (Iglesias et al., 2001). In this work it is proposed that sugar regulation may operate via ethylene, whereas GA functions as a repressor of the ethylene-sucrose stimulation. Therefore, GAs as well as nitrates are color break retardants since both delay the chloro- to chromoplast transition (Alós et al., 2006) in contrastethylene (Rodrigo and Zacarías, 2007).

While the mechanistic basis of color break in citrus has not yet been resolved, several other studies have suggested various factors that may contribute to pigment turnover. For example, it has been shown that chlorophyllase, a constitutively expressed gene, does not increase during natural fruit development (JacobWilk et al., 1999). In addition, the expression patterns of carotenoid biosynthetic genes and an associated abundance of carotenoids during ripening have recently been reported (Kato et al., 2004; Rodrigo et al., 2004; Alós et al., 2006). It is noteworthy that citrus peel contains the greatest diversity of carotenoids of any fruit studied to date and their specific accumulation patterns are responsible for the broad range of colors exhibited by 


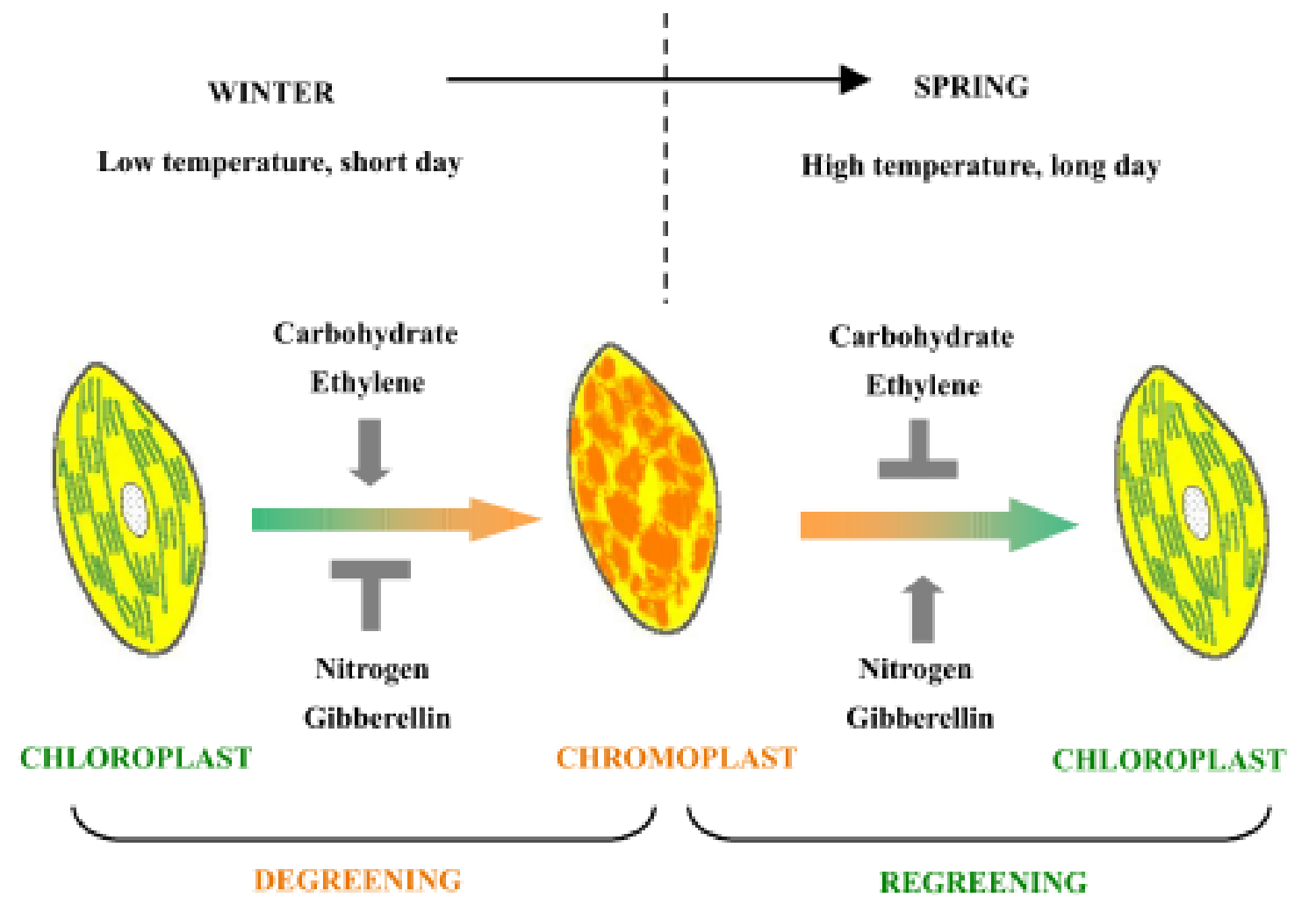

Figure 4. Regulation of color break in citrus fruits. External fruit ripening is dependent upon the conversion of chloroto chromoplast and involves the progressive loss of chlorophylls and the gain of carotenoids, changing peel color from green to orange. The changes associated with external ripening are influenced by environmental conditions, nutrient availability and hormones. De-greening in subtropical areas generally takes place in mid-autumn when temperatures go down and day length diminishes. Depletion of nitrogen appears to be a pre-requisite for color break but carbohydrate accumulation is thought to stimulate the process. Similarly, ethylene promotes de-greening and gibberellins counteract this process. Interestingly, the chloro- to chromoplast conversion is a reversible processes, even from fully differentiated chromoplasts. During spring, temperature rises and day length increases and these new environmental conditions induce new re-growth that results in nitrogen uptake, carbohydrate utilization and gibberellin synthesis. These changes presumably drive re-greening of the fruit peel.

citrus fruits (Gross, 1987). Although the characteristic color of typical citrus varieties is mainly provided by the accumulation of 9-cis-violaxanthin and $\beta$-cryptoxanthin, there are also citrus-specific carotenoids such as $\beta$ citraurin and $\beta$-citraurinene that provide an attractive coloration and whose biosynthetic basis remains unknown (Oberholster et al., 2001).

Mutants are very valuable plant materials to study specific genetic and physiological mechanisms. Collections of citrus mutations have been generated (Iglesias and Talon, unpublished results) and a whole lot of altered phenotypic characteristics and other deviations from wild type standards have been found in mutants showing alterations in physiological processes related to fruit growth, shape, size, quality and ripening (Alós et al., 2007; Figure 5). Citrus mutants altered in color change, for example, have been identified and are currently used to study the mechanisms involved in the control of this process (Figure 6, see below). A very useful mutant for this purpose is the so-called "navel negra" (nan, black navel), a spontaneous mutant of Washington Navel impaired in chlorophyll catabolism and thus exhibiting an abnormal brown color in the ripe flavedo.

Internal ripening: Mature citrus pulp contains a very high percentage of water (85-90\%) and many different constituents, including carbohydrates, organic acids, 


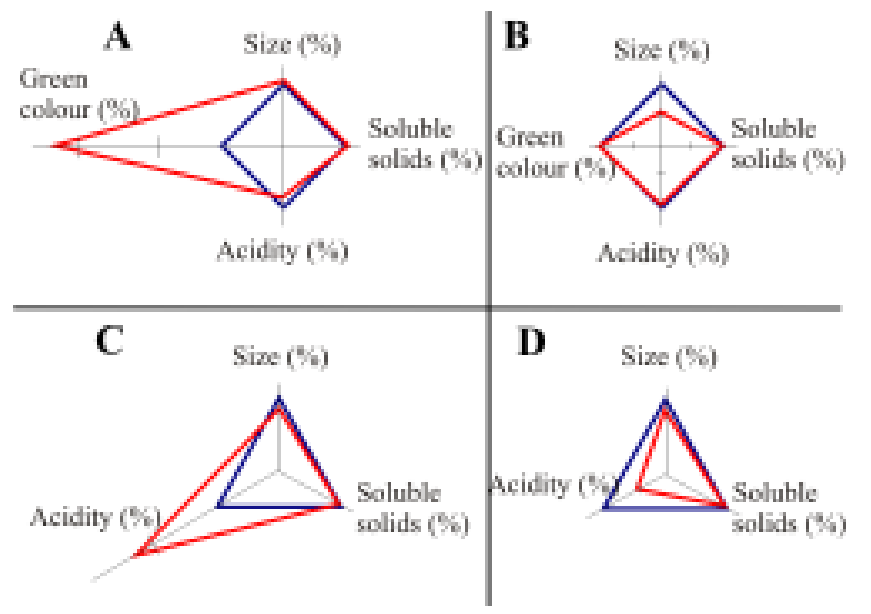

Figure 5. Simultaneous representation of fruit parameters in citrus mutants. Commercial traits at ripening are simultaneously compared among orange and mandarin fruits from mutant and parental genotypes. Citrus mutants belong to collections of induced mutations generated through physical and chemical mutagenic agents. A whole lot of altered phenotypic characteristics and other deviations from wild type standards are found in mutants showing distorted physiological processes related to fruit growth, shape, size, quality and ripening. Blue lines represent standard values $(100 \%)$ of parental fruit genotypes while red lines show the altered values of the mutant fruit genotypes. (A) Mutant genotype with a delayed color break and slightly reduced acidity. (B) Mutant genotype with no differences in the internal and external fruit ripening but with decreased size. (C) and (D) Mutant genotypes with altered internal ripening due to increased and decreased acidity, respectively.

amino acids, vitamin $\mathrm{C}$, minerals and small quantities of lipids, proteins, and secondary metabolites, such as carotenoids, flavonoids and volatiles (Davis and Albrigo, 1994). Total soluble solids comprise $10-20 \%$ of the fresh weight of the fruit, and consist mainly of carbohydrates (70-80\%), and relatively minor quantities of organic acids, proteins, lipids and minerals. During ripening, in general there is a decline in titratable acidity mostly due to catabolism of citric acid [the principal organic acid of citrus juice (Monselise, 1986)] and an increase in sugars, usually expressed as total soluble solids (Figure 7). The total soluble solids-to-titratable acidity ratio is commonly known as the maturity index.

The physiological processes regulating fruit development and ripening have been extensively studied because of the importance of fruits as components for the human diet (Giovannoni, 2004). In climacteric fruits and in

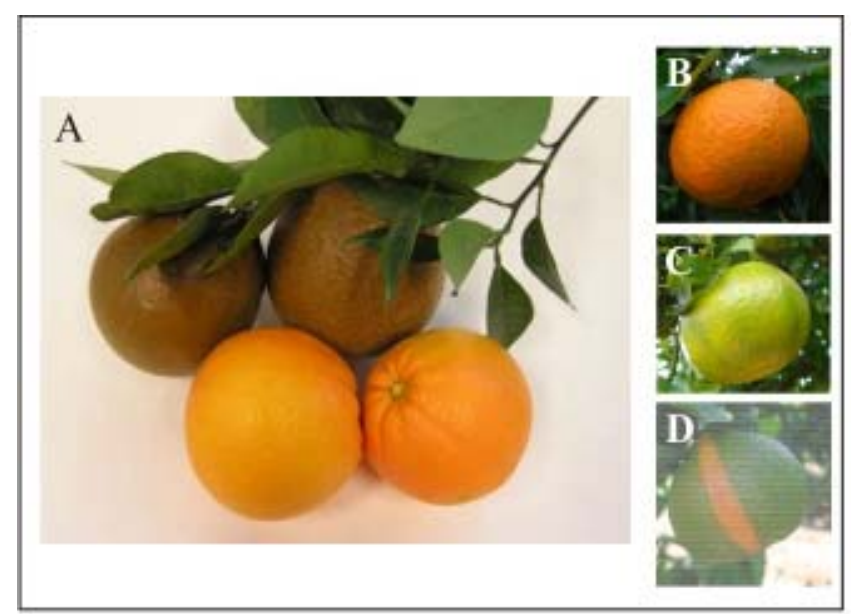

Figure 6. Peel color alterations in citrus mutants. Citrus mutants with altered patterns of color change in the fruit peel are valuable materials to study mechanisms regulating chlorophyll degradation and carotenoid deposition. (A) Fruits from normal and "nan" mutant cultivars of Washington Navel. The orange mutant nan ("navel negra", black navel), a spontaneous mutation causing impaired chlorophyll catabolism, exhibits an abnormal brown color in the ripe flavedo because of the concurrent occurrence of chlorophylls and carotenoids. (B) Fruits from normal cultivars of Clementina de Nules and (C) fruits from a deletion mutant cultivar of the same species generated with fast neutrons showing delayed color break. The mutation apparently slows down both chlorophyll catabolism and carotenoid synthesis. (D) Chimeral Clementine fruit showing color sectors.

particular in tomato, it has been demonstrated that ethylene controls ripening processes through the regulation of gene transcription and, therefore, much information has been generated in the areas of ethylene biosynthesis and response (reviewed in Giovannoni, 2004). In contrast, the mechanism of ripening control in non-climacteric fruits, including citrus, is totally unknown.

It is generally accepted that developing citrus fruitlets constitute main utilization sinks during the cell division period and act as carbohydrate storage sinks during the cell enlargement stage and thereafter (Mehouachi et al., 1995; Cercós et al., 2006). Recent molecular data obtained with global transcriptomic analyses of citrus fruit pulp suggested that in the middle and later stages of development carbohydrate synthesis and catabolism is mostly down-regulated while sugar transport appears to 


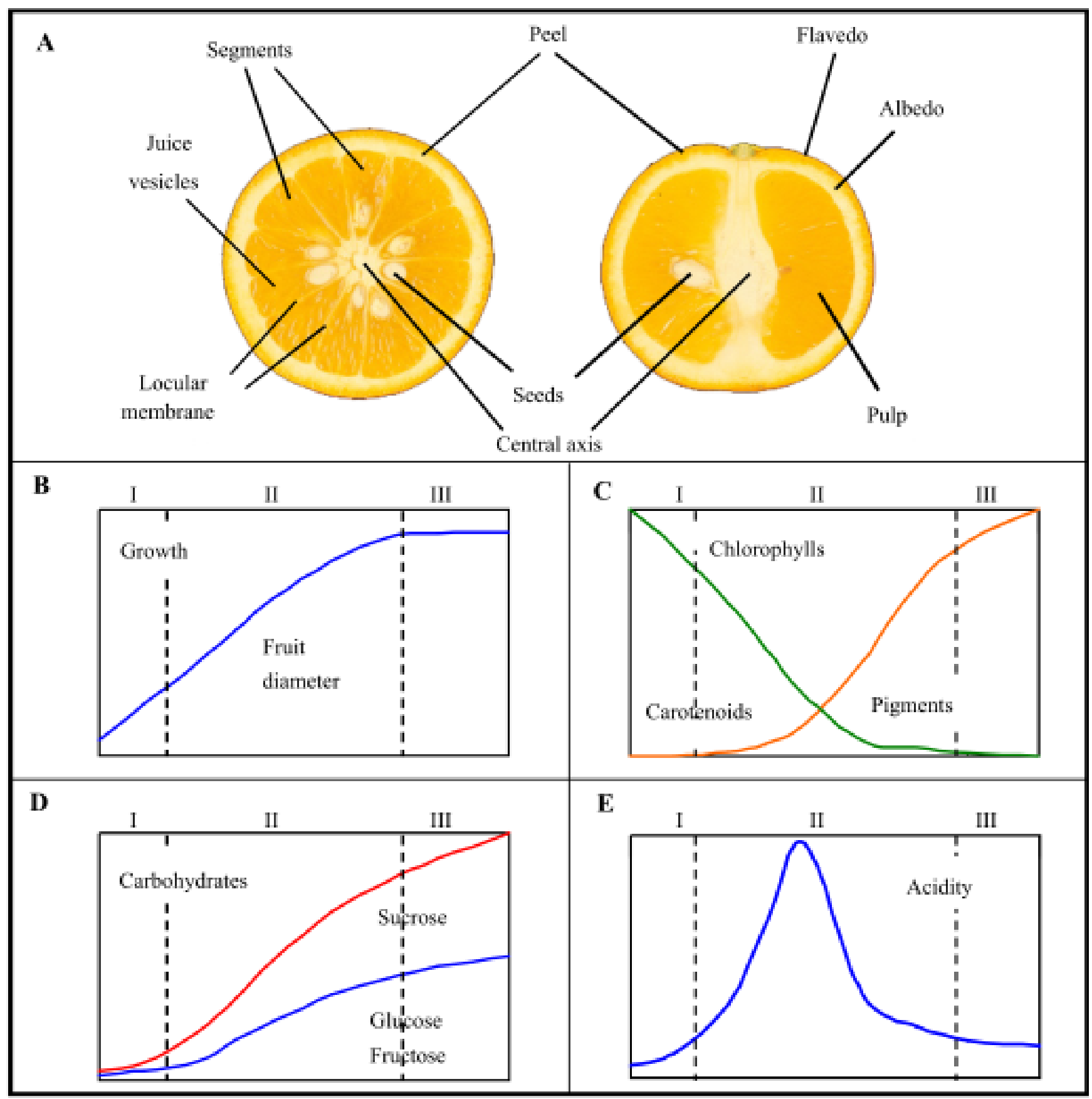

Figure 7. Structure of citrus fruit and metabolic changes associated with the internal development. (A) Internal structure of a ripe orange fruit. (B) Fruit growth is mostly due to cell divisions during phase I and to water accumulation, and therefore cell enlargement, during phase II. At the beginning of phase III, growth is arrested and fruit starts a nonclimacteric ripening process. (C) In contrast with peel flavedo, chlorophyll degradation and carotenoid biosynthesis in pulp proceed along phase II and therefore color break is reached earlier. This results in a progressive change in pulp color that contrasts with the rapid color break occurring in flavedo. (D) Paralleling fruit growth, high amounts of soluble carbohydrates are translocated to the developing fruit. Thus, mature citrus fruit pulp accumulates high amounts of sucrose, glucose and fructose in a 2:1:1 ratio. (E) Acid accumulation in fruit pulp takes place during phase I and the beginning of phase II, reaching a maximum around mid-phase II. Organic acids are catabolized through the end of phase II to attain during phase III the characteristic low acidity of ripe fruits. 
be rather operative (Cercós et al., 2006). Sink strength in citrus fruits has been associated with the presence of sucrose metabolizing enzymes, mainly sucrose synthase (Hockema and Etxeberria, 2001; Komatsu et al., 2002; Etxeberria et al., 2005), and in particular with a specific isoenzyme of this activity, CitSUSA, that is induced during citrus fruit ripening (Komatsu et al., 2002). Thus, while alkaline invertase and sucrose-phosphate synthase activities are mainly detected in the sink cells, sucrose synthase activity appears to be associated with the vascular bundles (Lowell et al., 1989; Tomlinson et al., 1991), specifically in the companion cells. In citrus fruit, juice sacs containing sink cells are physically separated from vascular bundles and hence the above observations indicate a role for sucrose synthase activity in phloem loading and unloading processes (Nolte and Koch, 1993). Thus, it has been suggested that thereafter, sucrosephosphate synthase activity may re-synthesize sucrose for further transport to the vacuoles (Komatsu et al., 2002). Post-phloem apoplastic transport of sucrose into the juice vesicles certainly occurs with very little hydrolysis (Koch and Avigne, 1990) indicating that sucrose import into the sink cells may well require sucrose transport through the apoplastic route into the vacuoles of the sink cells. In this regard, Etxeberria et al. (2005) demonstrated the existence of $\mathrm{H}^{+}$-sucrose symporters in the plasma membrane and also provided evidence for a subsequent endocytic transport system from the apoplast to the vacuole, a mechanism that allows direct incorporation of sucrose into the vacuole bypassing membrane transport.

During the first half of phase II, developing fruits also accumulate a considerable amount of organic acids in the vacuoles of the juice sac cells that are progressively catabolized over the second half of phase II through phase III. The physiological roles of organic acids are not clear; however, Hockema and Etxeberria (2001) suggested that low $\mathrm{pH}$ could result in enhanced sink strength, thus facilitating sugar accumulation. Organic acids contribute significantly to overall fruit quality and the regulation of acidity loss during ripening, although practically unknown, is a main constraint of the Citrus industry. Citric acid accounts for most of the titratable acidity in fruit juice $(80-90 \%)$ that also contains malate $(9-15 \%)$ and minor quantities of succinate and isocitrate (Baldwin, 1993).
Thus, acidity loss mostly concerns citrate utilization. Considerable evidence has been obtained comparing acidless and acidic varieties showing that activity and expression of citrate synthase was not responsible for differences in acid accumulation (Sadka et al., 2001). This appears to be a complex process controlled by many coordinated enzymes. Unpublished work in our lab, for example, suggests the involvement of malic enzymes besides several other activities in the citric acid accumulation phase. Another gene characterized in citrus was NADP(+)-isocitrate dehydrogenase (NADP-IDH), encoding an enzyme involved in citrate metabolism. Recently it has been reported a citrate transporter gene encoding a novel vacuolar citrate/symporter that is able to mediate citrate vacuolar efflux through the electroneutral co-transport of $\mathrm{H}+$ and citrate ions (Shimada et al., 2006). Furthermore, data from the transcriptomic study cited above together with the analyses of selected metabolites suggested the occurrence of specific metabolic alternatives during citric acid catabolism (Cercós et al., 2006). In this respect we proposed that citrate was sequentially metabolized to glutamate that was finally catabolized through the gamma-aminobutyrate (GABA) shunt. This observation is of special relevance since it links an efficient major proton consuming reaction with high acid levels. The suggestion also provides a convincing explanation for the strong reduction of both citrate and cytoplasmatic acidity that takes place in citrus fruit flesh during development and ripening. In a study work Katz et al. (2007) analyzed soluble and enriched membrane fractions of mature citrus fruit and identified $c a 1,400$ proteins of fruit juice cells including proteins involved in sugar metabolism, citrate cycle, signalling, transport, and processing. This effort may open new insights to the regulation of internal ripening in citrus. In a parallel approach, major proteins in the albedo of the fruit peel of matured on-tree fruits were identified through MS/MS (Lliso et al., 2007). This proteomic survey indicated that major changes in protein content in the albedo of the peel during the ageing process were apparently related to the activation of programmed cell death.

Secondary metabolism: Citrus fruit are very popular worldwide for their flavour and health properties since they contain a wide collection of secondary metabolites 
that originally address different plant needs but possess crucial nutritional properties. Oranges in particular are rich sources of vitamin $\mathrm{C}$, flavonoids, carotenoids (provitamin A), and other nutraceutical compounds. Furthermore, consumption of citrus fruits has been associated with improved health and reduction of risk of both cancer and cardiovascular diseases. These beneficial effects are probably due the action of obioactive compounds (Nishino et al., 2004; Arias and Ramon-Laca, 2005) and, hence, intake of these substances in the habitual diet is highly recommended because of their antioxidant properties (Franke et al., 2005). In addition, flower and fruit tissues also develop oil glands producing essential oils acting as signals to attract pollinators and seed dispersers as well as constituting crucial compounds for plant defense. Toxic chemicals operate to ward off pathogens and herbivores or to suppress growth of neighbouring plants. Citrus essence oils are a blend of different volatile compounds characterized for having a high content of terpenoids hydrocarbons and relative low amount of terpenoids oxygenated compounds. Volatile terpenoids along with alcohols, aldehydes, ketones and acids are responsible for much of the aroma and flavour of citrus fruits. Citrus essential oils accumulate in flavedo peel glands and oil bodies in the juice vesicles. Among terpenes, monoterpenes $(\mathrm{C} 10)$ and sesquiterpenes $(\mathrm{C} 15)$ are the major components (up to $90 \%$ ) of citrus essential oils, but only few of them display aroma activity. The monoterpene $(+)$-limonene is the major component of most citrus oils. However, its apparent aroma activity may be due to a co-eluting impurity since several sesquiterpenes present in small quantities have a profound effect on citrus fruit flavour and aroma (Högnadóttir and Roussef, 2003). The most intense orange essence oil aroma is produced by the terpene alcohol linalool (0.68\%), fatty aldehydes decanal and octanal, sesquiterpene aldehydes citronellal and $\beta$ sinensal, $\beta$-ionone (a carotenoid degradation product), and the cyclic ester wine lactone (Maccarone et al, 1998). No particular compound alone accounts for the aroma of oranges that is mostly the result of the interaction of different compounds. The distinctive fresh sweetness from the orange peel is mainly due to the sesquiterpene sinensal, specially the isomer (all-E)- $\alpha$-sinensal that has an odour detection threshold as low a $0.05 \mathrm{ppb}$
(Högnadóttir and Roussef, 2003).

Flavonoids (flavonols, flavanals, anthocyanidins, flavones and flavanones) are important secondary plant metabolites that result from chemical variants and substitutions of the basic structure C15 flavan nucleus. Flavonoids may account for a considerable proportion of total solids of citrus fruit and more than 60 have already been identified. Flavones described in orange are the polymethoxyflavones sinensetin, nobiletin, tangeretin and heptamethoxyflavone, and important flavanones are hesperidin and isonaringin (Del Río et al., 1998a,b). The tasteless flavanone hesperidin is the predominant flavonoid in most citrus fruits but its content depends upon the cultivar, environmental growing conditions and maturity stage (Mouly et al., 1997; Rapisarda et al., 1998). Polymethoxyflavones are biologically more active than flavanones (Arcas et al., 2000; Del Río et al., 2000) and both are mainly located in the peel, polymethoxyflavones in the flavedo and flavanones in the albedo (Kanes et al., 1992; Ortuño et al., 1997). Moreover, flavanones are important constituents of the bitter flavour of citrus fruit whereas anthocyanins are a subgroup of flavonoids responsible for the typical red color of the peel and pulp of blood orange varieties (Macaccarone et al., 1983, 1985).

\section{ABIOTIC CONSTRAINS INFLUENCING CITRUS FRUITING}

Commercial citrus varieties are generally grown as scions grafted onto a rootstock species adapted to the particular conditions of the region. Main abiotic factors influencing citrus fruiting are dependent upon the soil composition, the quality and quantity of water and the risk of cold temperatures. Other stresses such ozone exposure, for example, does not appear to be specifically relevant in citrus (Iglesias et al., 2006a). Citrus do not develop a powerful root system and in subtropical semiarid zones might experience water shortage in some seasons. This condition may lead to the use of low quality water for irrigation, thereby increasing salt concentration. Excess salts, especially high chloride, are rather detrimental to citrus fruit growth. Other negative soil characteristics such as excess calcium, high $\mathrm{pH}$ and mineral imbalances also affect citrus fruiting. In calcareous soils, for example, the high $\mathrm{pH}$ causes the 
precipitation of $\mathrm{Fe}$ in immobilized forms that are not available for plant absorption. This circumstance leads to iron chlorosis, one of the main causes of abiotic and nutritional problems in calcareous soils. Lastly, freezing temperatures have recurrently caused major problems in many citrus areas. Thus, salinity, water stress, iron chlorosis, flooding and freezing are the most common adverse environmental conditions for citrus. In general, these damaging stresses do not come alone but in combination, each having a negative influence on the other leading to restricted development. Although they may have specific responses, the common effects on vegetative and reproductive growth are essentially the same: abortion of development of inflorescences; reduction of fertility and fruit set; arrest of leaf and fruit growth; and abscission of reproductive and vegetative structures including buds, flowers, ovaries, developing fruitlets, ripe fruits and leaves.

Salinity: In citrus, vegetative and reproductive development and yield are seriously affected by salinity (Storey and Walker, 1999). Although substantial differences in salt tolerance have been described within different species, the genus Citrus can be classified as salt sensitive (Greenway and Munns, 1980). Salinity adversely influences several aspects of plant vegetative and reproductive growth. Among the physiological processes leading to general reduction of growth, photosynthetic activity, transpiration, stomatal conductance, and even root hydraulic conductivity have been shown to be decreased by salinity (Maas, 1993; Romero-Aranda et al., 1998; Moya et al., 1999; Arbona et al., 2005). Moreover, under these conditions, a wide range of plant nutritional deficiencies is also apparent (Alva and Syvertsen, 1991). Leaf abscission may also contribute to the salt-induced growth inhibition in citrus (Gómez-Cadenas et al., 1998) and phytohormones such as ABA and ethylene have been identified as main modulators of these responses (Gómez-Cadenas et al., 1998, 2003a,b). High salinity in irrigation water has been reported to reduce flowering intensity, fruit set, number of fruits, and fruit growth (Cole and McLeold, 1985; Howie and Lloyd, 1989). Furthermore, citrus fruits on trees irrigated with saline water often ripe earlier and are smaller. In general, yields have also been reported to be strongly affected for all citrus cultivars. The relationship between salinity and yield can normally be expressed as a negative linear response function (Maas and Hoffman, 1977). It has been reported that above a threshold conductivity value of $1.4 \mathrm{dS} \mathrm{m}^{-1}$, every $1 \mathrm{dS} \mathrm{m}^{-1}$ increase results in an average of $13 \%$ decrease in yield (Shalhevet and Levy, 1990; Maas, 1993).

Detrimental effects of salinity on plants include osmotic stress and ion toxicity (Serrano, 1996). While citrus plants are very sensitive to osmotic alterations produced by water shortage (Gómez-Cadenas et al., 1996), they adjust osmotically very rapidly and with high efficiency under saline conditions (Maas, 1993). Furthermore, ion accumulation immediately enables citrus leaves to reach normal or even higher turgor pressures (Bañuls et al., 1990; Gómez-Cadenas et al., 1996). Consequently, damage caused by salinity has been primarily associated with ion toxicity. It is generally accepted, however, that in citrus chloride $\left(\mathrm{Cl}^{-}\right)$ accumulation (Cooper, 1961; Walker et al., 1982; Bañuls and Primo-Millo, 1995; 1992; Bañuls et al., 1997; RomeroAranda et al., 1998; Moya et al., 2003) is rather more unfavorable than sodium $\left(\mathrm{Na}^{+}\right)$build-up. Furthermore, a clear relationship between leaf $\mathrm{Cl}^{-}$concentration and defoliation has been established (Behboudian et al., 1986; Lloyd et al., 1989; Bañuls and Primo-Millo, 1992; Storey, 1995). Thus, the physiological basis for citrus tolerance to salt stress is mostly related to the ability to limit leaf accumulation of $\mathrm{Cl}^{-}$, a mechanism particularly dependent upon the rootstock (Cooper et al., 1952; Behboudian et al., 1986; Maas, 1993; Bañuls and PrimoMillo, 1995; Romero-Aranda et al., 1998; Levy and Lifshitz, 1999; Storey and Walker, 1999). Additional ions have been reported to improve citrus performance during salt stress. Thus, supplementing either $\mathrm{Ca}^{2+}$ or nitrate to a saline root solution has been described to ameliorate the effects of salinity (Iglesias et al., 2004).

Very little is known of the mechanisms involved in uptake, subcellular distribution and long distance transport of $\mathrm{Cl}^{-}$by plants. Recently, a gene encoding for a secondary $\mathrm{Cl}^{-}$transporter involved in developmental processes and long-distance $\mathrm{Cl}^{-}$transport has been characterized (Colmenero-Flores et al., 2007). At high salinities (e.g. $>60 \mathrm{mM} \mathrm{Cl}^{-}$) diffusive mechanisms through the apoplast may also constitute important pathways for $\mathrm{Cl}^{-}$uptake in citrus plants (Syvertsen et al., 1989; Moya et al., 1999; 2003). 
Water stress: In temperate areas, natural citrus growth is usually limited by water deficiency affecting both vegetative and reproductive processes. High temperatures together with dry environments induce tree dehydration and in this situation growth is generally prevented and abscission stimulated. It has been mentioned above that water stress is a strong inducing factor of flowering but aside from this stimulating effect many other physiological parameters are negatively affected by water stress. Characteristic leaf injuries and abscission are typical consequences of water deficit conditions (Tudela and Primo-Millo, 1992). After long exposure to water deficit, gas exchange parameters, $\mathrm{CO}_{2}$ assimilation, water potential and stomatal conductance are progressively affected (Gómez-Cadenas et al., 1996). These alterations provoke a general decrease in both vegetative growth and reproductive processes. Moderate water deficits may reduce fruit set, particularly in seedless cultivars, although seeded varieties are also affected when drought is more severe. Maximum effects on fruit abscission are observed during the June drop, the period of highest sensitivity to water deficit (Nakajima et al., 1993; Ginestar and Castel, 1996). Combinations of dry winds and high temperatures may also produce similar effects to those promoted by water stress, even in the presence of soil humidity. Under severe dryness and desiccation fruit quality is compromised (Yakushiji et al., 1998), fruit growth is reduced, fruit abscission is elevated and final yield can be dramatically shortened (Blanke and Bower, 1991).

Citrus apparently have a peculiar behavior regarding leaf and fruit abscission induced by water stress. These organs normally do not fall during the period of water stress but they suddenly do so after re-hydration (Addicott, 1982). In citrus, both growth attenuation and abscission activation have been primarily associated with increases in ABA content (Takahashi et al., 1975; Talon et al., 1990b; Sagee and Erner, 1991; Zacarias et al., 1995). Moreover, it is well established that leaf abscission in water-stressed citrus is also regulated by ethylene (Tudela and Primo-Millo, 1992), although again previous ABA accumulation is required for abscission to occur (Gómez-Cadenas et al., 1996). Interestingly, it has been shown that the hormonal sequence triggering fruitlet abscission under water deficit is the same that operates during natural ovary and fruitlet abscission, as explained above. Accordingly, the sequence of events leading to leaf abscission is as follows: water stress $\rightarrow$ ABA accumulation in roots $\rightarrow$ ACC accumulation in roots $\rightarrow$ $\mathrm{ACC}$ transport from roots to shoots $\rightarrow$ ACC oxidation to ethylene in leaves $\rightarrow$ leaf abscission (Gómez-Cadenas et al., 1996). These results suggest that ABA, the primary sensitive signal to water stress, modulates the levels of ethylene, the hormonal activator of leaf abscission (Figure 8). Although the occurrence of this sequence has not specifically been studied in developing fruits, the above observations suggest that fruit abscission induced by water deficit very plausibly follows the same sequence. Thus, a variety of developmental and environmental stimuli appear to operate or to act through a single hormonal pathway.

In addition, the occurrence of antagonistic changes between the levels of ABA and GAs in developing citrus fruitlets subjected to changing water conditions has also been reported (Mehouachi et al., 1995), representing a negative relationship similar to that suggested above to occur during natural abscission of early fruitlets. Recently, several ABA biosynthetic genes involved in water deficit responses have been described in citrus. A relationship between $\mathrm{ABA}$ accumulation in response to drought and the expression of genes of the carotenoid cleavage dioxygenase family has been reported in both vegetative and reproductive tissues (Agustí et al., 2007).

Iron chlorosis: The most important nutritional disorder in crop plants grown in alkaline soils with high carbonates is Fe deficiency, the so-called "lime-induced chlorosis or iron chlorosis". In citrus, Fe chlorosis is a major yieldlimiting concern. It has been estimated, for example, that $20-50 \%$ of fruit trees grown in the Mediterranean basin suffer from Fe deficiency (Jaeger et al., 2000). At pH values above 5 , iron in the $\mathrm{Fe}^{3+}$ form reacts with $\mathrm{HCO}_{3}^{-}$ forming insoluble metal oxides that cannot be absorbed by the plants. High bicarbonates, therefore, reduce Fe uptake, translocation and utilization (Mengel, 1995) and since $\mathrm{Fe}$ is a fundamental element for chlorophyll synthesis and thylakoid stabilization, an evident effect of Fe deficiency is a decrease of photosynthetic pigments, leading to yellowing of plant foliage (Abadía, 1992; Pestana et al., 2001). In many plants, leaf veins usually remain more or less green because Fe is poorly redistributed within the tissue. Iron deficiency in citrus 

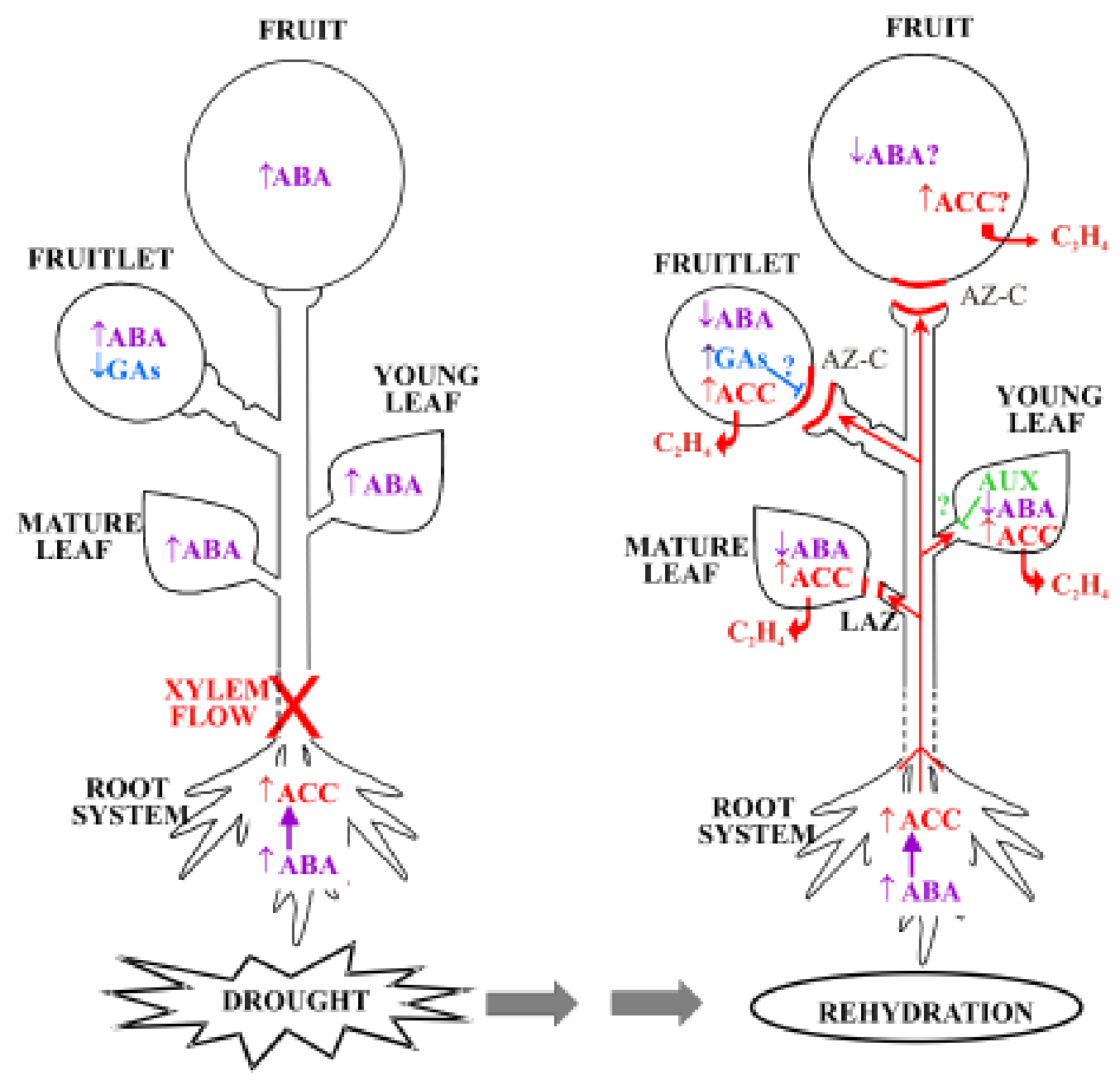

Figure 8. Regulation of water stress-induced abscission. In stressed roots, severe water-stress induces interruption of xylem flow and accumulation of abscisic acid (ABA). Subsequently, ABA drives 1-aminocyclopropane-1-carboxylic acid (ACC, the immediate precursor of ethylene) accumulation. In the aerial parts of the plant, water stress induces ABA increases and gibberellin (GAs) decreases while ACC is not modified. Re-hydration restores xylem movement and reduces $\mathrm{ABA}$ and $\mathrm{ACC}$ levels in roots. After re-hydration, ABA decreases in aerial organs whereas ACC is actively transported to leaves, fruitlets and fruit where is catabolized to ethylene $\left(\mathrm{C}_{2} \mathrm{H}_{4}\right)$, the hormonal activator of abscission. In non-abscising fruitlets, a rise in GA levels appears to act as a negative regulator of abscission. Reproductive organs (fruitlets and fruits) and mature leaves are shed through the calyx abscission zone (AZ-C) and laminar abscission zone (LAZ), respectively. However, young leaves do not shed after re-hydration. Young leaves are rich sources of endogenous plant hormones such as auxins (AUX) that may operate as abscission inhibitors. Up and down minor arrows near hormone names indicate increase or decrease in hormone levels, respectively. Arrows and T-shaped lines indicate positive and negative regulation, respectively.

also alters leaf and flower mineral composition, reduces photosynthate concentration and is responsible for significant decreases in yield, fruit size and fruit quality (El-Kassas, 1984; Pestana et al., 2001, 2003). Citrus fruit on $\mathrm{Fe}$ deficient trees are smaller and more acidic with lower vitamin C content (El-Kassas, 1984). Furthermore, Fe chlorosis may also delay fruit ripening.
Flooding: Severe seasonal rainfall and the consequent water excess can produce soil waterlogging and submergence, collectively termed flooding, within a few hours, especially in areas with poorly drained soils. Flooding affects soils by altering soil structure, depleting $\mathrm{O}_{2}$, accumulating $\mathrm{CO}_{2}$, inducing anaerobic decomposition of organic matter, and reducing solubility of iron and 
manganese (Kozlowski, 1997; Liao and Lin, 2001; Jackson and Colmer, 2005). Most soils suitable for growing citrus become reduced within a few days of flooding (Syvertsen et al., 1983; Davis and Albrigo, 1994). For example, sulfides are reduced to hydrogen sulfide by sulfur-fixing bacteria and this conversion is rather damaging to citrus roots in view of their high sensitivity to hydrogen sulfide. Another major constraint resulting from excess water is the inadequate supply of oxygen to submerged tissues. Under these conditions, uptake of macronutrients is decreased because of suppression of root functionality and hormonal balances are altered, usually favoring ethylene production. In the shoot, flooding reduces stomatal conductance and net $\mathrm{CO}_{2}$ assimilation, leading to photosynthesis inhibition, altered production and transport of carbohydrates (Phung and Knipling, 1976) and oxidative damages (Gómez-Cadenas, unpublished results). Reduced transpiration impairs hydraulic root conductivity, and hence water uptake (Syvertsen et al., 1983; Vu and Yelenosky, 1991; Pezeshki et al., 1996). In addition, waterlogged soils are very propitious to the proliferation of soil-borne fungi such as Phytophtora. In this regard, the extent of root damage is a function of soil temperature, organic matter content and microbial activity (Davis and Albrigo, 1994). Waterlogging inhibits initiation of flower buds, anthesis, fruit set, and fruit growth. Fruit quality is also reduced since the chemical composition and appearance of fruits is altered and the size diminished. Excess water also provokes fruit burst or crack especially when long periods of drought precede soil waterlogging (Kaufmann, 1972).

\section{CONCLUSIONS AND PERSPECTIVES}

This revision presents information on the physiological bases of the regulation of citrus fruit growth, while progress in elucidating the overall genetic network controlling fruit development is being reviewed elsewhere (Talon and Gmitter, 2008; Tadeo el al., 2008). Despite the challenges of working with this long-lived perennial tree, the present review clearly shows that substantial progress has already been made. However, fruit are very complex plant organs and the regulation of their development is extremely complicated. In spite of these advances the information summarized above indicates that there is still an enormous task ahead before a comprehensive model of the mechanisms underlying fruit development can be formulated.

The major phenotypical and physiological differences that are present among plant species, despite the high level of conservation of biological function in all organisms, clearly show that a single plant model cannot be used to answer all biological questions. In this regard, Citrus may provide the opportunity to study many questions related to flowering and fruiting that cannot be easily addressed in Arabidopsis or even tomato, the two favourite models for dicots. The unusual reproductive biology of Citrus certainly brings new challenges in the analyses of genetic and phenotypic variation. In addition, all tree-specific traits controlling and influencing flowering, fruit development, abscission and ripening are also obvious major areas of research. Thus, many central biological questions including juvenility, alternate flowering and bearing, apomixis, self-incompatibility, parthenocarpy, non-climacteric development, fruit drop etc., are currently a challenge and mostly still need to be resolved. Interestingly, many of them, for example the characterization of nutraceuticals and volatiles, have major economical implications. It is also clear that the lack of knowledge on the pivotal physiological and genetic mechanisms underlying these critical questions raises major obstacles to the generation of proper strategies required for a substantial production and availability of citrus fruits in a global and competitive world. We hope that the acquisition of this understanding will speed up the invention and application of novel cultural practices and help in the development of more adapted varieties. If this is the case, citrus will continue to be an economically valuable fruit crop and a source of important health and nutrition benefits.

Acknowledgements: Work at Centro de Genómica was supported by INIA grants RTA04-013 and 05-247, INCO contract 015453 and Ministerio de Educación y Ciencia grant AGL2007-65437-C04-01/AGR. Help and expertise of A. Almenar, E Blázquez, A. Boix, I. López, A. López García-Usach, I. Sanchís and M. Sancho are gratefully acknowledged. 


\section{REFERENCES}

Abadía J (1992) Leaf response to iron deficiency. J. Plant Nutr. 15:1699-1713.

Abbott CE (1935) Blossom-bud differentiation in citrus trees. Am. J. Bot. 22:476-485.

Addicott FT (1982) Abscission. University of California Press, Berkeley.

Agustí M, Zaragoza S, Iglesias DJ, Almela V, Primo-Millo E, Talon M (2002) The synthetic auxin 3,5,6-TPA stimulates carbohydrate accumulation and growth in citrus fruit. Plant Growth Regul. 36:43-49.

Agustí J, Zapater M, Iglesias DJ, Cercós M, Tadeo FR, Talon M (2007) Differential expression of putative 9cis-epoxycarotenoid dioxygenases and abscisic acid accumulation in water stressed vegetative and reproductive tissues of citrus. Plant Sci. 172:85-94.

Aharoni Y (1968) Respiration of oranges and grapefruit harvested at different stages of development. Plant Physiol. 43:99-102.

Albrigo LG (1999) Effects of foliar applications of urea or nutriphite on flowering and yields of Valencia orange trees. Proc. Fla. Sta. Hort. Soc. 112:1-4.

Alós E, Cercós M, Rodrigo MJ, Zacarias L, Talon M (2006) Regulation of color break in citrus fruits. Changes in pigment profiling and gene expression induced by gibberellins and nitrate, two ripening retardants. J. Agric. Food Chem. 54:4888-4895.

Alós E, Agustí J, Brumós J, Carrera E, Cercos M, Colmenero-Flores JM, Conesa A, Ibáñez V, Iglesias D, Lliso I, Lopez A, Mínguez-Mosquera MI, Naranjo MA, Rios G, Roca M, Rodrigo MJ, Rose J, Ruiz O, Soler G, Tadeo F, Terol J, Zacarias L, Talon M (2007) Transcriptomic analyses of natural and induced mutants of citrus reveal key genes limiting physiological processes of major relevance to the citrus industry. Plant Genomics European Meeting 5, Venice, Italy.

Altman A, Goren R (1974) Growth and dormancy cycles in Citrus bud cultures and their hormonal control. Physiol. Plant. 30:240-245.

Altman A, Goren R (1978) Development of Citrus bud explants in culture. J. Am. Soc. Hort. Sci. 103:120-123.

Alva AK, Syvertsen JP (1991) Irrigation water salinity affects soil nutrient distribution, root density, and leaf nutrient levels of citrus under drip fertigation. J. Plant Nutr. 14:715-727.
Arbona V, Marco A, Iglesias DJ, López-Climent MF, Talon M, Gómez-Cadenas A (2005) Carbohydrate depletion in roots and leaves of salt-stressed potted Citrus clementina L. Plant Growth Reg. 46:153-160.

Arcas MC, Botía JM, Ortuño A, Del Río JA (2000) UV irradiation alters the levels of flavonoids involved in the dense mechanism of Citrus aurantium fruits against Penicillium digitatum. Eur. J. Plant Pathol. 106:617-622.

Arias BA, Ramon-Laca L (2005) Pharmacological properties of citrus and their ancient medieval uses in the Mediterranean region. J. Ethnopharmacol. 10:89-95.

Azuma R, Kurata H, Adachi M, Shimokawa K (1999) Degreening of Citrus unshiu fruits via ethyleneinduced soluble chlorophyllase. J. Jap. Soc. Hort. Sci. 68:558-562.

Bain JM (1958) Morphological anatomical and physiological changes in the developing fruit of the Valencia orange Citrus sinensis L. Osbeck. Aust. J. Bot. 6:1-24.

Baldwin EA (1993) Citrus fruit. In: Seymour GB, Taylor JE, Tucker GA (eds), Biochemistry of Fruit Ripening, pp.107-149. Chapman \& Hall, London.

Bañuls J (1990) Behaviour of several variety-rootstock combinations of citrus against salinity. Valencia, University of Valencia, PhD thesis.

Bañuls J, Primo-Millo E (1992) Effects of chloride and sodium on gas exchange parameters and water relations of Citrus plants. Physiol. Plant. 86:115-123.

Bañuls J, Primo-Millo E (1995) Effects of salinity on some citrus scion-rootstock combinations. Ann. Bot. 76:97-102.

Bañuls J, Serna MD, Legaz F, Talon M, Primo-Millo E (1997) Growth and gas exchange parameters of Citrus plants stressed with different salts. J. Plant Physiol. 150:194-199.

Behboudian MH, Törökfalvy E, Walker RR (1986) Effects of salinity on ionic content, water relations and gas exchange parameters in some citrus scion-rootstock combinations. Sci. Hort. 28:143-146.

Bellows TS Jr, Lovatt CJ (1989) Modelling flower development in Citrus. In: Wright CJ (ed), Manipulation of Fruiting, pp.115-129, Butterworth \& Co., London.

Ben-Arie R, Mignani I, Greve C, Huysamer M, Labavitch JM (1995) Regulation of the ripening of tomato 
pericarp discs by $\mathrm{GA}_{3}$ and divalent cations. Physiol. Plant. 93:99-107.

Ben-Cheikh W, Perez-Botella J, Tadeo FR, Talon M, Primo-Millo E (1997) Pollination increases gibberellin levels in developing ovaries of seeded varieties of citrus. Plant Physiol. 114:557-564.

Blanke M, Bower JP (1991) Small fruit problem in citrus trees. Trees 5:239-243.

Brown KM (1997) Ethylene and abscission. Physiol. Plant. 100:567-576.

Bruinsma J, Knegt E, Varga H (1975) The role of growth regulating substances in fruit ripening. In: Facteurs et Regulation de la Maturation des Fruits, pp.193-199. Centre National de la Recherche Scientifique, Paris.

Bustan A, Goldschmidt EE (1998) Estimating the cost of flowering in a grapefruit tree. Plant Cell Environ. 21:217-224.

Cassin J, Bourdeaut J, Fougue A, Furon V, Gaillard JP, LeBourdelles J, Montagut G, Moreuil C (1969) The influence of climate upon blooming of citrus in tropical areas. Proc. $1^{\text {st }}$ Int. Citrus Symp. 1:315-323.

Catala C, Rose JKC, Bennett AB (2000) Auxin-regulated genes encoding cell wall-modifying proteins are expressed during early tomato fruit growth. Plant Physiol. 122:527-534.

Cercós M, Soler G, Iglesias DJ, Gadea J, Forment J, Talon M (2006) Global analysis of gene expression during development and ripening of citrus fruit flesh. A proposed mechanism for citric acid utilization. Plant Mol. Biol. 62:513-527.

Chaikiattiyos S, Menzel CM, Rasmussen TS (1994) Floral induction in tropical fruit trees effects of temperature and water supply. J. Hort. Sci. 69:397-415.

Chen HQ, Dekkers KL, Cao L, Burns JK, Timmer LW, Chung KR (2006) Evaluation of growth regulator inhibitors for controlling postbloom fruit drop (PDF) of citrus induced by the fungus Colletotrichum acutatum. Hort. Sci. 41:1317-1321.

Coggins CW, Hield HZ (1968) Plant-growth regulators. In: Reuther W, Batchelor LD, Webber HJ (eds.) The Citrus Industy, Vol. 11, pp.371-389. University of California Press, Berkeley.

Cole PJ, McLeod PI (1985) Salinity and climatic effects on the yield of citrus. Aust. J. Exp. Agric. 25:711-717.

Colmenero-Flores JM, Martinez G, Gamba G, Vazquez N, Iglesias DJ, Brumos J, Talon M (2007) Identification and functional characterization of cation-chloride cotransporters in plants. Plant J. 50:278-292.

Cooper WC, Gorton BS (1952) Toxicity and accumulation of chloride salts in citrus on various rootstocks. Proc. Am. Soc. Hort. Sci. 59:143-146.

Cooper WC (1961) Toxicity and accumulation of salts in citrus trees on various rootstocks in Texas. Proc. Fla. Sta. Hort. Soc. 74:95-104.

Cooper WC, Henry WH (1972) Effect of growth regulators on the response of citrus fruit to cycloheximideinduced abscission. Proc. Fla. Sta. Hort. Soc. 85:29-32.

Cooper WC, Henry WH (1968) Effect of growth regulators on the coloring and abscission in citrus fruit. Isr. J. Agric. Res. 18:161-174.

Davenport TL (1990) Citrus flowering. In: Janick J (ed), Horticultural Review, Vol. 12, pp.349-408. Timber Press, Portland.

Davis FS, Albrigo LG (1994) Citrus. In: Crop Production Science in Horticulture Series, pp.134-135. CAB International, Wallington.

Del Río JA, Arcas MC, Benavente O, Sabater F, Ortuño A (1998a) Changes of polymethoxylated flavones levels during development of Citrus aurantium cv. Sevillano fruits. Planta Med. 6:575-576.

Del Río JA, Arcas MC, Benavente-García O, Ortuño A (1998b) Citrus polymethoxylated flavones can confer resistance against Phytophtora citrophthora, Penicillium digitatum, and Geotrichum species. J. Agric. Food Chem. 46:4423-4428.

Del Río JA, Arcas MC, Botía JM, Avidez A, Fuster MD, Ortuño A (2000) Involvement of phenolic compounds in the antifungal defense mechanisms of Olea europea L. and Citrus sp. In: Pandalai SG (ed.), Recent Research Developments in Agricultural and Food Chemistry, Vol. 4, pp.331-341. Research Signpost, Trivandrum.

Downton WJS, Grant WJR, Loveys BR (1987) Carbon dioxide enrichment increases yield of Valencia orange. Aust. J. Plant Physiol. 14:493-501.

Eaks IL (1970) Respiratory response ethylene production and response to ethylene of citrus fruit during ontogeny. Plant Plysiol. 45:334-338.

Eilati SK, Ilionselise SP, Budowski P (1969) Seasonal development of external color and carotenoid content in the peel of ripening 'Shamouti' oranges. J. Am. Soc. Hort. Sci. 94:346-348. 
El-Kassas SE (1984) Effect of iron nutrition on the growth, yield, fruit quality, and leaf composition of seed balady lime trees grown on sandy calcareous soils. J. Plant Nutr. 7:301-311.

Erickson LC, Brannaman BL (1960) Abscission of reproductive structures and leaves of orange trees. Proc. Am. Soc. Hort. Sci. 75:222-229.

Erner Y (1988) Effects of girdling on the differentiation of inflorescence types and fruit set in 'Shamouti' orange trees. Isr. J. Bot. 37:173-180.

Etxeberria E, Gonzalez P, Pozueta-Romero J (2005) Sucrose transport into citrus juice cells. Evidence for an endocytic transport system. J. Am. Soc. Hort. Sci. 130:269-274.

Fagoaga C, Vidal AM, Tadeo FR, Lliso I, Iglesias D, Talon M, Navarro L, García-Martínez JL, Peña L (2007) Engineering of gibberellin levels in citrus by sense and antisense overexpression of a GA 20-oxidase gene modifies plant architecture. J. Exp. Bot. 58:1407-1420.

Forment J, Gadea J, Huerta L, Abizanda L, Agusti J, Alamar S, Alós E, Andres F, Berbel A, Blázquez MA, Brumos J, Cercos M, Colmenero-Flores JM, Conesa A, Estables B, Gandia M, Garcia-Martinez JL, Gimeno J, Gisbert A, Gomez G, Gonzalez-Candelas L, Granell A, Guerra J, Lafuente T, Madueno F, Marcos JF, Martinez F, Martinez-Godoy MA, Miralles S, Moreno P, Navarro L, Pallas V, Perez-Amador MA, Perez-Valle J, Pons C, Rodrigo I, Rodríguez P, Royo C, Serrano R, Soler G, Tadeo F, Talon M, Terol J, Trenor M, Vaello L, Vicente O, Vidal CH, Zacarias L, Conejero V (2005) Development of a citrus genome-wide EST collection and cDNA microarray as resources for genomic studies. Plant Mol. Biol. 57:375-391.

Franke AA, Cooney RV, Henning SM, Custer LJ (2005) Bioavailability and antioxidant effects of orange juice components in humans. J. Agric. Food Chem. 53:51705178.

Frost HB, Soost RK (1968) Seed reproduction: development of gametes and embryos. In: Reuther W, Barchelor LD, Webber HJ (eds), The Citrus Industry, Vol. 2, pp.290-320. University of California, California.

Fujii H, Shimada T, Sugiyama A, Nishikawa F, Endo T, Nakano M, Ikoma Y, Shimizu T, Omura M (2007) Profiling ethylene-responsive genes in mature mandarin fruit using a citrus $22 \mathrm{~K}$ oligoarray. Plant Sci. 173:340-348.
Garcia-Luis A, Almela V, Monerri C, Agustí M, Guardiola JL (1986) Inhibition of flowering in vivo by existing fruits and applied growth regulators in Citrus unshiu. Physiol. Plant. 66:515-520.

Garcia-Luis A, Santamarina P, Guardiola JL (1989) Flower formation from Citrus unshiu buds cultured in vitro. Ann. Bot. 64:515-519.

Garcia-Luis A, Kanduser M, Santamarina P, Guardiola JL (1992) Low temperature influence on flowering in Citrus. The separation of inductive and bud dormancy releasing effects. Physiol. Plant. 86:648-682.

García-Papí MA, García-Martínez JL (1984) Endogenous plant growth substances content in young fruits of seeded and seedless Clementine mandarin as related to fruit set and development. Sci. Hort. 22:265-274.

Gillaspy G, Ben-David H, Gruissem W (1993) Fruits: a developmental perspective. Plant Cell 5:1439-1451.

Ginestar C, Castel JR (1996) Responses of young Clementine citrus trees to water stress during different phenological periods. J. Hort. Sci. 71:551-559.

Giovannoni J (2004) Genetic regulation of fruit development and ripening. Plant Cell 16:S170-S180.

Goldschmidt EE (1988) Regulatory aspects of chlorochromoplast interconvensions in senescing Citrus fruit peel. Isr. J. Bot. 47:123-130.

Goldschmidt EE (1999) Carbohydrate supply as a critical factor for citrus fruit development and productivity. HortScience 34:1020-1024.

Goldschmidt EE, Huberman M (1974) The coordination of organ growth in developing Citrus flowers: a possibility for sink type regulation. J. Exp. Bot. 25:534541.

Goldschmidt EE, Koch KE (1996) Citrus. In: Zaminski E, Schaffer AA (eds), Photoassimilate Distribution in Plants and Crops: Source-Sink Relations, pp.797-823. Marcel Dekker, New York.

Goldschmidt EE, Monselise SP (1977) Physiological assumptions toward the development of a citrus fruiting model. Proc. Int. Soc. Citrus 2:668-672.

Goldschmidt EE, Huberman M, Goren R (1993) Probing the role of endogenous ethylene in the degreening of citrus fruit with ethylene antagonists. Plant Growth Regul. 12:325-329.

Gómez-Cadenas A, Tadeo FR, Talon M, Primo-Millo E (1996) Leaf abscission induced by ethylene in water stressed intact seedlings of (Citrus reshni Hort. ex 
Tan.) requires previous abscisic acid accumulation in roots. Plant Physiol. 112:401-408.

Gómez-Cadenas A, Tadeo FR, Primo-Millo E, Talon M (1998) Involvement of abscisic acid and ethylene in the response of citrus seedlings to salt shock. Physiol. Plant. 103:475-484.

Gómez-Cadenas A, Mehouachi J, Tadeo FR, Primo-Millo E, Talon M (2000) Hormonal regulation of fruitlet abscission induced by carbohydrate shortage in citrus. Planta 210:636-643.

Gómez-Cadenas A, Arbona V, Jacas J, Primo-Millo E, Talon M (2003a) Abscisic acid reduces leaf abscission and increases salt tolerance in citrus plants. J. Plant Growth Regul. 21:234-240.

Gómez-Cadenas A, Iglesias DJ, Arbona V, ColmeneroFlores JM, Primo-Millo E, Talon M (2003b) Physiological and molecular responses of citrus to salinity. Recent Res. Devel. Plant Mol. Biol. 1:281-298.

Goren R (1993) Anatomical, physiological and hormonal aspects of abscission in Citrus. Hort. Rev. 15:33-46.

Goto A, Yamane H, Takahashi N, Hirose K (1989) Identification of nine gibberellins from young fruits of Satsuma mandarin (Citrus unshiu Marc.). Agric. Biol. Chem. 53:28172818.

Greenway H, Munns R (1980) Mechanisms of salt tolerance in non-halophytes. Annu. Rev. Plant Physiol. 31:149-190.

Gross J (1987) Pigments in Fruits. Academic Press, London.

Guardiola JL, Monerri C, Agustí M (1982) The inhibitory effect of gibberellic acid on flowering in Citrus. Physiol. Plant. 55:136-142.

Guis M, Botondi R, Ben-Amor M, Ayub R, Bouzayen M, Pech J, Latché A (1997) Ripening-associated biochemical traits of Cantaloupe Charentais melons expressing an antisense ACC oxidase transgene. J. Am. Soc. Hort. Sci. 122:748-751.

Hartmond U, Yuan R, Burns JK, Grant A, Kender WJ (2000) Citrus fruit abscission induced by methyljasmonate. J. Am. Soc. Hort. Sci. 125:547-552.

Hernández FM, Primo-Millo E (1990) Studies on endogenous cytokinins in Citrus. J. Hort. Sci. 65:595601 .

Hockema BR, Etxeberria E (2001) Metabolic contributors to drought-enhanced accumulation of sugars and acids in oranges. J. Am. Soc. Hort. Sci. 126:599-605.
Högnadóttir A, Roussef RL (2003) Identification of aroma active compounds in orange essence oil using gas chromatography-olfactometry and gas chromatography-mass spectrometry. J. Chromatogr A. 998:201-211.

Howie H, Lloyd J (1989) Response of orchard 'Washington navel' orange, Citrus sinensis (L.) Osbeck to saline irrigation water. 2. Flowering, fruit set and fruit growth. Aust. J. Agric. Res. 40:371-380.

Huff A (1983) Nutritional control of regreening and degreening in Citrus peel segments. Plant Physiol. 73:243-249.

Huff A (1984) Sugar regulation of plastid interconversions in epicarp of Citrus fruit. Plant Physiol. 76:307-312.

Iglesias DJ, Tadeo FR, Legaz F, Primo-Millo E, Talon M (2001) In vivo sucrose stimulation of colour change in citrus fruit epicarps: interactions between nutritional and hormonal signals. Physiol. Plant. 112:244-250.

Iglesias DJ, Lliso I, Tadeo FR, Talon M (2002) Regulation of photosynthesis through source: sink imbalance in citrus is mediated by carbohydrate content in leaves. Physiol. Plant. 116:563-569.

Iglesias DJ, Tadeo FR, Primo-Millo E, Talón M (2003) Fruit set dependence on carbohydrate availability in citrus tress. Tree Physiol. 23:199-204.

Iglesias DJ, Levy Y, Gómez-Cadenas A, Tadeo FR, PrimoMillo E, Talon M (2004) Nitrate improvement of growth in salt stressed citrus seedlings through effects on photosynthetic activity and chloride accumulation. Tree Physiol. 24:1027-1034.

Iglesias DJ, Calatayud A, Barreno E, Primo-Millo E and Talon M (2006a) Responses of citrus plants to ozone: growth, antioxidant mechanisms and lipid peroxidation. Plant Physiol. Biochem. 44:125-131.

Iglesias DJ, Tadeo FR, Primo-Millo E, Talon M (2006b) Carbohydrate and ethylene levels regulate citrus fruitlet drop through the abscission zone A during early development. Trees 20:348: 355.

Iwahori S, Garcia-Luis A, Santamarina P, Monerri C, Guardiola JL (1990) The influence of ringing on bud development and flowering in satsuma mandarin. J. Exp. Bot. 41:1341-1346.

Jackson MB, Colmer TD (2005) Response and adaptation by plants to flooding stress. Ann. Bot. 96:501-505. 
Jacob-Wilk D, Holland D, Goldschmidt EE, Riov J, Eyal Y (1999) Chlorophyll breakdown by chlorophyllase: isolation and functional expression of the Chlase 1 gene from ethylene-treated Citrus fruit and its regulation during development. Plant J. 20:653-661.

Jaeger B, Goldbach H, Sommer K (2000) Release from lime induced iron chlorosis by cultan in fruit trees and its characterisation by analysis. Acta Hort. 531:107-114.

Jahn OL (1973) Inflorescence types and fruiting patterns in 'Hamlin' and 'Valencia' oranges and 'Marsh' grapefruit. Am. J. Bot. 60:663-670.

Kanes K, Tisserat B, Berhow M, Vandercook C (1992) Phenolic composition of various tissues of rutaceae species. Phytochemistry 32:967-974.

Kato M, Ikoma Y, Matsumoto H, Sugiura M, Hyodo H, Yano M (2004) Accumulation of carotenoids and expression of the carotenoid biosynthetic genes during maturation in citrus fruit. Plant Physiol. 134:114.

Katz E, Martinez-Lagunes P, Riov J, Weiss D, Goldschmidt EE (2004) Molecular and physiological evidence suggests the existence of a system II-like pathway of ethylene production in non-climacteric Citrus fruit. Planta 219:243-252.

Katz E, Fon M, Lee YJ, Phinney BS, Sadka A, Blumwald E (2007) The citrus fruit proteome: insights into citrus fruit metabolism. Planta 226:989-1005.

Kaufmann MR (1972) Water deficits and reproductive growth. In: Kozlowski TT (ed) Water Deficits and Plant Growth, Vol. III, pp.91-124. Academic Press, New York.

Koch KE, Avigne WT (1990) Postphloem, nonvascular transfer in Citrus. Plant Physiol. 93:1405-1416.

Komatsu A, Moriguchi T, Koyama K, Omura M, Akihama $T$ (2002) Analysis of sucrose synthase genes in citrus suggests different roles and phylogenetic relationships. J. Exp. Bot. 53:61-71.

Koshita Y, Takahara T, Ogata T, Goto A (1999) Involvement of endogenous plant hormones (IAA, ABA, GAs) in leaves and flower bud formation of satsuma mandarin (Citrus unshiu Marc.). Sci. Hort. 79:185-194.

Kozlowski TT (1997) Responses of woody plants to flooding and salinity. Tree Physiol. Monograph 1:1-29.

Lahey KA, Yuan R, Burns JK, Ueng PP, Timmer LW, Chung KR (2004) Induction of phytohormones and differential gene expression in citrus flowers infected by the fungus Colletotrichum acutatum. Mol. Plant Microbe-Interact. 17:1394-1401.

Lenz F (1967) Relationships between the vegetative and reproductive growth of Washington navel oranges cuttings (Citrus sinensis L. Osbeck). J. Hort. Sci. 42:3139.

Levy Y, Lifshitz J (1999) The response of several citrus genotypes to high-salinity Irrigation Water. HortScience 34:878-881.

Liao CT, Lin CH (2001) Physiological adaptation of crop plants to flooding stress. Proc. Natl. Sci. Counc. 25:148-157.

Lliso I, Forner JB, Talon M (2004) The dwarfing mechanism of the citrus rootstocks F\&A 418 and \#23 is related to the competition between vegetative and reproductive development. Tree Physiol. 24:225-232.

Lliso I, Tadeo FR, Phinney BS, Wilkerson CG, Talon M (2007) Protein changes in the albedo of citrus fruits on post-harvesting storage. J. Agric. Food Chem. 55: 9047-9053.

Lloyd J, Kriedemann P, Aspinall D (1989) Comparative sensitivity of Prior Lisbon lemon and Valencia orange trees to foliar sodium and chloride concentrations. Plant Cell Environ. 12:529-540.

Lord EM, Eckard KJ (1985) Shoot development in Citrus sinensis L. (Washington Navel orange). I. Floral and inflorescence ontogeny. Bot. Gaz. 146:320-326.

Lovatt C J, Streeter SM, Minter SM, O'Connell NV, Flaherty DL, Freeman MW, Goodell PB (1984) Phenology of flowering in Citrus sinensis (L.) Osbeck, cv. "Washington navel orange". V Proc. Int. Soc. Citric. 1:186-190.

Lovatt CJ, Zheng Y, Hake CD (1988) Demonstration of a change in nitrogen metabolism influencing flower initiation in Citrus. Isr. J. Bot. 37:181-188.

Lowell CA, Tomlinson PT, Koch KE (1989) Sucrosemetabolizing enzymes in transport tissues and adjacent sink structures in developing citrus fruit. Plant Physiol. 90:1394-1402.

Maas EV (1993) Salinity and citriculture. Tree Physiol. 12:195-216.

Maas EV, Hoffman GJ (1977) Crop salt tolerance-current assessment. J. Irrig. 103:115-134.

Maccarone E, Maccarone A, Rapisarda P (1985) Acylated anthocyanins from oranges. Ann. Chim. 75:79-86. 
Maccarone E, Maccarone A, Perrini G, Rapisarda P (1983) Anthocyanins of the Moro orange juice. Ann. Chim. 73:533-539.

Maccarone E, Campisi S, Fallico B, Rapisarda P, and Sgarlata R (1998) Flavor components of Italian orange juices. J. Agric. Food Chem. 46:2293-2298.

McGlasson WB, Wade NL, Adato I (1978) Phytohormones and fruit ripening. In: Letham DS, Goodwin PB Higgins TJ (eds) Phytohormones and Related Compounds - A Comprehensive Treatise, Vol. 2, pp.447-493. Elsevier/North Holland Biomed. Press, Amsterdam.

Mehouachi J, Serna D, Zaragoza S, Agusti M, Talon M, Primo-Millo E (1995) Defoliation increases fruit abscission and reduces carbohydrate levels in developing fruits and woody tissues of Citrus unshiu. Plant Sci. 107:189-197.

Mehouachi J, Tadeo FR, Talon M, Primo-Millo E (1996) Effects of gibberellic acid and paclobutrazol on growth and carbohydrate accumulation in shoots and roots of citrus rootstock seedlings. J. Hort. Sci. 71:747-754.

Mehouachi J, Iglesias DJ, Tadeo FR, Agustí M, PrimoMillo E, Talon M (2000) The role of leaves in citrus fruitlet abscission: effects on endogenous gibberellin levels and carbohydrate content. J. Hort. Sci. Biotechnol. 75:79-85.

Mehouachi J, Gómez-Cadenas A, Primo-Millo E, Talon M (2005) Antagonistic changes between abscisic acid and gibberellins in citrus fruits subjected to a series of different water conditions. J. Plant Growth Regul. 24:179-187.

Mengel K (1995) Iron availability in plant tissues-iron chlorosis on calcareous soils. Plant Soil 165:275-283.

Menino MR, Carranca C, de Varennes A, d'Almeida VV, Baeta J (2003) Tree size and flowering intensity as affected by nitrogen fertilization in non-bearing orange trees grown under Mediterranean conditions. J. Plant Physiol. 160:1435-1440.

Mesejo C, Martínez-Fuentes A, Reig C, Agustí M. (2007) The effective pollination period in 'Clemenules' mandarin, 'Owari' Satsuma mandarin and 'Valencia' sweet orange. Plant Sci. 173:223-230.

Monselise SP (1985) Citrus and related species. In: Halevy AH (ed), CRC Handbook of Flowering, Vol. 2, pp.275-294. CRC Press, Boca Raton.
Monselise SP (1986) Citrus. In: Monselise SP (ed), Handbook of Fruit Set and Development, pp.87-108. CRC Press, Boca Raton.

Moss GI (1969) Influence of temperature and photoperiod on flower induction and inflorescence development in sweet orange (Citrus sinensis L. Osbeck). J. Hort. Sci. 44:311-320.

Moss G I, Steer BT, Kriedmann PE (1972) The regulatory role of inflorescence leaves in fruit setting by sweet orange (Citrus sinensis). Physiol. Plant. 27:432-438.

Moss GI (1973) The influence of temperature during flower development on the subsequent fruit-set of sweet orange (Citrus sinensis) 'Washington Navel'. Hort. Res. 13:65-73.

Mouly PP, Gaydou EM, Faure R, Estienne JM (1997) Blood orange juice authentication using cinnamic acid derivates. Variety differentiations associated with flavanone glycoside content. J. Agric. Food Chem. 45:373-377.

Moya JL, Primo-Millo E, Talon M (1999) Morphological factors determining salt tolerance in citrus seedlings: the shoot to root ratio modulates passive root uptake of chloride ions and their accumulation in leaves. Plant Cell Environ. 22:1425-1433.

Moya JL, Gómez-Cadenas A, Primo-Millo E, Talon M (2003) Chloride absorption in salt-sensitive Carrizo citrange and salt-tolerant Cleopatra mandarin citrus rootstocks is linked to water usage. J. Exp. Bot. 54:825833.

Nakajima Y, Susanto S, Hasegawa K (1993) Influence of water stress in autumn on flower induction and fruiting in young pomelo trees (Citrus grandis (L.) Osbeck). J. Jap. Soc. Hort. Sci. 62:15-20.

Nauer EM, Boswell SB (1981) Stimulating growth of quiescent Citrus buds with 6-benzylaminopurine. HortScience 16:162-163.

Nebauer SG, Avila C, García-Luis A, Guardiola JL (2006) Seasonal variation in the competence of the buds of three cultivars from different Citrus species to flower. Trees 20:507-514.

Nir I, Goren R, Leshem B (1972) Effects of water stress, gibberellic acid, 2-chloroethyltrimethylammonium chloride (CCC) on flower differentiation in 'Eureka' lemon trees. J. Am. Soc. Hort. Sci. 97:774-778.

Nishino H, Tokuda H, Satomi Y, Masuda M, Osaka Y, Yogosawa S, Wada S, Mou XY, Takayasu J, Murakoshi 
M, Jinnno K, Yano M (2004) Cancer prevention by antioxidants. Biofactors 22:57-61.

Nolte KD, Koch KE (1993) Companion-cell specific localization of sucrose synthase in zones of phloem loading and unloading. Plant Physiol. 101:899-905.

Oberholster R, Cowan K, Molnar P, Toth G (2001) Biochemical basis of color as an aesthethic quality in Citrus sinensis. J. Agric. Food Chem. 49:303-307.

Ortuño A, Reynaldo I, Fuster MD, Botía, JM, García-Puig D, Sabater F, García-Lidón A, Porras I, Del Río JA (1997) Citrus cultivars with high flavonoid contents in the fruits. Sci. Hort. 68:233-236.

Pestana M, David M, de Varennes A, Abadía J, Faria EA (2001) Responses of "Newhall" orange trees to iron deficiency in hydroponics: effects on leaf chlorophyll, photosynthetic efficiency, and root ferric chelate reductase activity. J. Plant Nutr. 24:1609-1620.

Pestana M, de Varennes A, Faria EA (2003) Diagnosis and correction of iron chlorosis in fruit trees: a review. J. Food Agric. Environ. 1:46-51.

Pezeshki SR, Pardue JH, DeLaune RD (1996) Leaf gas exchange and growth of flood-tolerant and floodsensitive tree species under low soil redox conditions. Tree Physiol. 16:453-458.

Phung JT, Knipling EB (1976) Photosynthesis and transpiration of citrus seedlings under flooded conditions. HortScience 11:131-133.

Porat R, Feng X, Huberman M, Galili D, Goren R, Goldschmidt EE (2001) Gibberellic acid slows postharvest degreening of Oroblanco citrus fruits. HortScience 36:937-940.

Powell AA, Krezdorn AH (1977) Infuence of fruit-setting treatment on translocation of $14 \mathrm{C}$-metabolites in citrus during flowering and fruiting. J. Am. Soc. Hort. Sci. 102:709-714.

Rapisarda P, Carollo G, Fallico B, Tomaselli F, Maccarone E (1998) Hydroxycinnamic acids as markers of Italian blood orange juices. J. Agric. Food Chem. 465:464-470.

Rivas F, Gravina A, Agusti M (2007) Girdling effects on fruit set and quantum yield efficiency of PSII in two Citrus cultivars. Tree Physiol. 27:527-535.

Rodrigo MJ, Marcos JF, Zacarías L (2004) Biochemical and molecular analysis of carotenoid biosynthesis in flavedo of orange (Citrus sinensis L.) during fruit development and maturation. J. Agric. Food Chem. 52:6724-6731.
Rodrigo MJ, Zacarias L (2007) Effect of postharvest ethylene treatment on carotenoid accumulation and the expression of carotenoid biosynthetic genes in the flavedo of orange (Citrus sinensis L. Osbeck) fruit. Postharvest Biol. Technol. 43:14-22.

Roitsch T (1999) Source-sink regulation by sugar and stress. Curr. Opin. Plant Biol. 2:198-206.

Romero-Aranda R, Moya JL, Tadeo FR, Legaz F, PrimoMillo E, Talon M (1998) Physiological and anatomical disturbances induced by chloride salts in sensitive and tolerant citrus: beneficial and detrimental effects of cations. Plant Cell Environ. 21:1243-1253.

Sadka A, Dahan E, Or E, Roose ML, Marsh KB, Cohen L (2001) Comparative analysis of mitochondrial citrate synthase gene structure, transcript level and enzymatic activity in acidless and acid-containing Citrus varieties. Aust. J. Plant Physiol. 28:383-390.

Sagee O, Erner Y (1991) Gibberellins and abscisic acid contents during flowering and fruit set of Shamouti orange. Sci. Hort. 48: 29-39.

Serrano R (1996) Salt tolerance in plants and microorganisms: toxicity targets and defense responses. Int. Rev. Cytol. 165:1-52.

Shalhevet J, Levy Y (1990) Citrus trees. In: Stewart BA, Nielsen DR (eds), Irrigation of Agricultural Crops, pp.951-986. American Society of Agronomy, Madison.

Shimada T, Nakano R, Shulaev V, Sadka A, Blumwald E (2006) Vacuolar citrate $/ \mathrm{H}^{+}$symporter of citrus juice cells. Planta 224:472-480.

Soost RK, Burnett RH (1961) Effect of gibberellin on yield and fruit characteristics of Clementine mandarin. Proc. Am. Soc. Hort. Sci. 77:194 201.

Southwick SM and Davenport TL (1986) Characterization of water stress and low temperature effects on flower induction in Citrus. Plant Physiol. 81:26-29.

Spiegel-Roy P, Goldschmidt EE (1996) Biology of Citrus. Cambridge University Press, Cambridge.

Storey R (1995) Salt tolerance, ion relations and the effect of root medium on the response of citrus to salinity. Aust. J. Plant Physiol. 22:101-114.

Storey R, Walker RR (1999) Citrus and salinity. Sci. Hort. 78:39-81.

Syvertsen JP, Zablotowicz RM, Smith ML Jr (1983) Soil temperature and flooding effects on two species of citrus. I. Plant growth and hydraulic conductivity. Plant Soil 72:3-12. 
Syvertsen JP, Boman B, Tucker DPH (1989) Salinity in Florida Citrus production. Proc. Fla. Sta. Hort. Soc. 102:61-64.

Syvertsen JP, Lloyd J (1994) Citrus. In: Schaffer B, Andersen PC (eds), Handbook of Environmental Physiology of Fruit Crops, Vol. 2, pp.65-99. Boca Raton, CRC Press.

Syvertsen JP, Goñi C, Otero A (2003) Fruit load and canopy shading affect leaf characteristics and net gas exchange of "Spring" navel orange trees. Tree Physiol. 23:899-906.

Tadeo FR, Cercós M, Colmenero-Flores JM, Iglesias DJ, Naranjo MA, Ríos G, Carrera E, Ruiz-Rivero O, Lliso I, Morillon R, Talon M (2008) Molecular physiology of development and quality of citrus. Adv. Bot. Res. (in press).

Takahashi N, Yamagushi I, Kono T, Igoshi M, Hirose K, Suzuki K (1975) Characterization of plant growth substances in Citrus unshiu and their change in fruit development. Plant Cell Physiol. 16:1101-1111.

Talon M, Gmitter FG Jr (2008) Citrus Genomics. Int. J. Plant Genomics (in press).

Talon M, Zeevaart JAD (1992) Stem elongation and changes in the levels of gibberellins in shoots tips induced by photoperiodic treatments in the longh day plant Silene armeria. Planta 188:457-461.

Talon M, Hedden P, Primo-Millo E (1990a) Gibberellins in Citrus sinensis: a comparison between seeded and seedless varieties. J. Plant Growth Regul. 9: 201-206.

Talon M, Tadeo FR, Zeevaart JAD (1991) Cellular changes induced by exogenous and endogenous gibberellins in the shoot tips of the long-day plant Silene armeria. Planta 185:487-493.

Talon M, Zacarias L, Primo-Millo E (1990b) Hormonal changes associated with fruit set and development in mandarins differing in their parthenocarpic ability. Physiol. Plant. 79:400-406.

Talon M, Zacarias L, Primo-Millo E (1992) Gibberellin and parthenocarpic ability in developing ovaries of seedless mandarins. Plant Physiol. 99:1575-1581.

Terol J, Conesa A, Colmenero JM, Cercos M, Tadeo F, Agusti J, Alós E, Andres F, Soler G, Brumos J, Iglesias DJ, Gotz S, Legaz F, Argout X, Courtois B, Ollitrault P, Dossat C, Wincker P, Morillon R, Talon M (2007) Analysis of 13000 unique Citrus clusters associated with fruit quality, production and salinity tolerance.
BMC Genomics 8:31.

Tisserat B, Galletta PD, Jones D (1990) In vitro flowering from Citrus lemon lateral buds. J. Plant Physiol. 136:5660.

Tomlinson PT, Duke ER, Nolte KD, Koch KE (1991) Sucrose synthase and invertase in isolated vascular bundles. Plant Physiol. 97:1249-1252.

Trebitsh T, Goldschmidt EE, Riov J (1993) Ethylene induces de novo synthesis of chlorophyllase, a chlorophyll degrading enzyme, in Citrus fruit peel. Proc. Natl. Acad. Sci. USA 90:9441-9445.

Tudela D, Primo-Millo E (1992) 1-Aminocyclopropane-1carboxylic acid transported from roots to shoots promotes leaf abscission in Cleopatra Mandarin (Citrus reshni Hort. ex Tan.) seedlings rehydrated after water stress. Plant Physiol. 100:131-137.

Turnbull CGN (1989) Identification and quantitative analysis of gibberellins in Citrus. J. Plant Growth Regul. 8:273 282.

Valiente JI, Albrigo LG (2004) Flower bud induction of sweet orange trees [Citrus sinensis (L.) Osbeck]: effect of low temperatures, crop load, and bud age. J. Am. Soc. Hort. Sci. 129:158-164.

Vidal AM, Ben-Cheikh W, Talon M, García-Martínez JL (2003) Regulation of gibberellin 20-oxidase gene expression and gibberellin content in citrus by temperature and citrus exocortis viroid. Planta 217:442-448.

Vidal AM, Gisbert C, Talon M, Primo-Millo E, López-Díaz I, García-Martínez JL (2001) The ectopic overexpression of a citrus gibberellin 20-oxidase alters the gibberellin content and induces an elongated phenotype in tobacco. Physiol. Plant. 112:251-260.

Vu JCV, Yelenosky G (1991) Photosynthetic responses of citrus trees to soil flooding. Physiol. Plant. 81:7-14.

Walker RR, Törökfalvy E, Downtown WJS (1982) Photosynthetic responses of the Citrus varieties Rangpur lime and Etrog citron to salt treatment. Aust. J. Plant Physiol. 9:783-790.

Wallerstein I, Goren R, Ben-Tal Y (1978) Effect of ringing on root starvation in sour orange seedling. J. Hort. Sci. 53:109-113.

Yakushiji H, Morinaga K, Nonami H (1998) Sugar accumulation and partitioning in Satsuma mandarin tree tissues and fruit in response to drought stress. J. Am. Soc. Hort. Sci. 123:719-726. 
Yamanishi OK (1995) Trunk strangulation and winter heating effects on fruit size, internal quality and maturation of 'Tosa Buntan' pummelo grown in a plastic house. J. Hort. Sci. 70:65-74.

Yuan R, Hartmond, U, Kender WJ (2001) Physiological factors affecting response of mature "Valencia" orange fruit to $\mathrm{CMN}$-pyrazole. II. Endogenous concentrations of indole-3-acetic acid, abscisic acid, and ethylene. J. Am. Soc. Hort. Sci. 126:420-426.

Zacarias L, Talon M, Ben-Cheick W, Lafuente MT, Primo-
Millo E (1995) Abscisic acid increases in non-growing and paclobutrazol treated fruits of seedless mandarins. Physiol. Plant. 95:613-619.

Zeevaart JAD, Gage DA, Talon M (1993) Gibberellin A is required for stem elongation in spinach. Proc. Natl. Acad. Sci. USA 90:7401-7405.

Zhou L, Jan JC, Jones TL, Sheen J (1998) Glucose and ethylene signal transduction crosstalk revealed by an Arabidopsis glucose-insensitive mutant. Proc. Natl. Acad. Sci. USA 95:10294-10299. 